\title{
HOW DOES VIETNAM'S ACCESSION TO THE WORLD TRADE ORGANIZATION CHANGE THE SPATIAL INCIDENCE OF POVERTY?
}

\author{
Tomoki Fujii and David Roland-Holst
}

Trade policies can promote aggregate efficiency, but the ensuing structural adjustments generally create both winners and losers. From an incomes perspective, trade liberalization can raise GDP per capita, but rates of emergence from poverty depend upon individual household characteristics of economic participation and asset holding. To fully realize the growth potential of trade, while limiting the risk of rising inequality, policies need to better account for microeconomic heterogeneity. One approach to this is the geographic targeting, which shifts resources to poor areas. This study combines an integrated microsimulation-CGE model with the small area estimation to evaluate the spatial incidence of Vietnam's accession to the World Trade Organization. Provincial-level poverty reduction after full liberalization was heterogeneous, ranging from 2.2 per cent to 14.3 per cent. Full liberalization will benefit the poor on a national basis, but the northwestern area of Vietnam is likely to lag behind. Furthermore, poverty can be shown to increase under comparable scenarios.

\section{INTRODUCTION}

Trade liberalization is good for growth, and growth is good for the poor. This argument is simple but powerful. It has served as the departure point for discussion of the link between trade and poverty among economists and policy-makers, regardless of whether and to what extent they buy this argument. Krueger (1998) considers the inefficiencies that import substitution strategy creates and argues that trade liberalization undertaken at a period of low or negative growth rates can normally lead to a period of higher 
growth rates. Bhagwati and Srinivasan (2002) emphasize the empirical evidence of China and India. That is, these two giant economies achieved faster growth and poverty reduction through greater integration into the world economy. Dollar and Kraay (2002, 2004) use cross country regression to support this argument.

However, there are also many researchers who have strong reservations about this argument for at least two reasons. The first is methodological, Rodriguez and Rodrik (2001) for example severely criticized earlier studies supporting this argument because the measurement or the method is flawed. Ravallion (2001) points out that working with aggregate numbers can be misleading.

The second reason is the possibility of an adverse impact of trade liberalization on the poor. As pointed out by Winters (2002), there are a number of reasons why the poor may be adversely affected by trade liberalization. Important links include the change in prices of goods and services that poor households transact in relatively large amounts. Trade liberalization and poverty are also connected though government revenue and vulnerability of the economy to negative external shocks. Winters et al. (2004) provide an extensive survey on the relationship between trade liberalization and poverty. While they find no simple relationship, the empirical evidence broadly supports the notion that trade liberalization alleviates poverty in the long run and on an average basis. Yet, trade liberalization almost always creates winners and losers, and the losers may well include poor people.

Trade liberalization would be difficult to justify from the standpoint of poverty reduction if it adversely affects this group. This point is especially important in a country where a substantial portion of the population lives below or close to the poverty line. Aggregate growth alone is not enough to justify trade liberalization policies, particularly if poverty could worsen. Governments may not want to forgo liberalization, but must carefully choose the right mixture of policies, and be ready to implement mitigating policies when necessary.

Some argue that it is indeed possible to do so. Using a computable general equilibrium (CGE) model with a detailed panel of households, Harrison et al. (2003) argue that 
trade liberalization in Turkey can be designed to ensure that the poor will not lose by using direct compensation to the losers or by using limited policy reform. Their research is an improvement from previous work with very limited treatment of heterogeneity among households. However, making side payments for particular segments of households is not straightforward. As they noted, limited policy reform may induce rent-seeking.

In this study, we consider geographic targeting as a way to direct progressively more resources to areas that are least favourably affected by trade liberalization. Geographic targeting has several advantages. It is easy to understand and straightforward to implement. The distortion caused by geographic targeting is usually considered small because the cost of changing locations, especially for the poor, is often prohibitively high. Further, many countries already have some sort of programmes targeted to poor areas. We only need to modify the set of areas to make the programme more efficient for poverty reduction, instead of implementing a new programme. Hence, given the pre-existence of such a programme, the political cost would also be relatively small.

Of course, the formulation of an effective policy of geographic targeting requires the knowledge of the changes in spatial distribution of the poor after market liberalization. Economic research has provided only limited guidance in this area, because socioeconomic survey data with high temporal and spatial resolution needed for poverty monitoring are usually unavailable. Although policy makers need information on detailed incidence of trade liberalization, prior studies on these impacts were able to provide estimates only for a few representative household categories, very limited spatial decomposition or none at all.

To overcome the limitations of previous studies and elucidate more detailed incidence, we synthesize microsimulation, economy-wide CGE modeling, and small area estimation in an application to Vietnam's WTO accession. This new generation of analytical tools reveals the incidence of trade liberalization at an unprecedented level of microeconomic and spatial detail. The basic idea is straightforward; Economy-wide CGE modelling allows us to find the impacts of trade liberalization on aggregate sectors, which, in trun is translated by microsimulation into the impacts for households 
and individuals in the survey. We then use small area estimation to find the impacts for small geographic areas.

We present our results in the form of maps, which help policy makers visualize the spatial impact of trade liberalization on the poor, facilitating the design and implementation of geographically-targeted assistance. The approach set forth in this paper is readily applicable to other countries and can help enlarge the scope of the benefits of trade liberalization across a wider variety of countries and populations. Our study sheds new light on the geographic properties of poverty. It also helps to resolve the conflicts between 'Finance Ministry' and 'Civil Society' orientations, as described by Kanbur (2001), by offering a solution in which all the relevant parties including the poor can enjoy the benefits of trade liberalization.

The paper is organized as follows: in Section 2, we review relevant studies on trade liberalization and poverty in Vietnam. Section 3 describes the data sets we use and discusses the measurement of poverty. We then develop the methodology in Section 4. We first explain the schematic structure of the methodology and then present it formally. Section 5 presents the results, followed by conclusions in Section 6 .

\section{TRADE LIBERALIZATION AND POVERTY IN VIETNAM}

Since the introduction of Doi Moi (Renovation) in 1986 and further market-oriented reforms in 1989, most of the elements of Vietnam's centrally-planned trade regime had been removed by the early 1990s. These reform policies were extremely successful and resulted in very high growth rates of output and exports. The reform generally continued through the late 1990s and tariff measures associated with membership in the ASEAN Free Trade Area (AFTA) were implemented. Since then, the bilateral trade agreement between Vietnam and the United States in 2000 has given additional momentum to the reform process.

As standard economic theory would predict, trade liberalization has generally been beneficial to the overall Vietnamese economy and to its trading partners. Fukase and Martin (2000) estimate that aggregate Vietnamese welfare gains from the US granting 
most-favoured-nation status would be about USD 118 million annually, or about 1 per cent higher average real income per capita. Using a multi-sector CGE model, Heng and Gayathri (2004) predict that participation in the ASEAN-China Free Trade and the ASEAN-Japan Free Trade agreements will bring about positive and significant welfare gains to Vietnam. The CGE simulation of various trade liberalization policies by Fukase and Martin (2001) also suggests that the higher level of welfare can be achieved from more comprehensive liberalization. It is beyond dispute that market-oriented reforms have contributed to poverty reduction in Vietnam. Jenkins (2004) argues that improved employment brought about by the growth of exports is one potential way in which globalization has had a positive impact on poverty.

As part of its accession agreement, Vietnam has made substantial commitments to trade policy reforms. These include lowered import tariffs, reduced coverage of tariff rate quotas, removal of export subsidies and non-tariff barriers, the opening of some service sectors, compliance with the agreements of trade-related investment measures (TRIMs) and trade-related intellectual property rights (TRIPs). Further, the state owned enterprises need also to be reformed. ${ }^{1}$ Anderson (1999) argues that after the successful accession to the WTO, and given that some appropriate measures are taken, a number of broad-brush effects can be anticipated, including economic growth, expansion of agriculture and export-oriented light manufacturing, enhanced food security, more equitable income distribution, and increased government revenue.

However, the higher economic growth induced by further liberalization does not automatically imply reductions in poverty or inequality. Jensen and Tarp (2005), for example, predict that poverty will rise following a revenue-neutral lowering of trade taxes. Niimi et al. (2004) show that the employment in garment and textiles industries has been adversely affected in the 1990s by trade policies. Liu (2001) analyzes poverty and inequality of Vietnam using the Vietnam Living Standards Surveys (VLSS) 1992-93 and 1997-98. While Vietnam achieved a very rapid poverty reduction before the US

\footnotetext{
${ }^{1}$ See Thanh (2005) for further discussion on the process and progress of Vietnam's efforts to become a WTO member.
} 
bilateral trade agreement or WTO accessions, rural areas have lagged behind urban areas and overall inequality has increased slightly. Decomposition of inequality measures shows that urban-rural and regional differences have been the major source of rising national inequality over time.

Indeed, not everyone in Vietnam has benefited from the broad improvement in living standards, as indicated by results such as Litchfield and Justino (2004). Using the VLSS datasets, their regression model of the change in consumption suggests that there are large differences in household performance in different regions. Glewwe et al. (2002) also reported similar findings using the VLSS datasets.

One of the factors that significantly affected the probability of escaping poverty during the 1990s was location. Urban households, as well as households in the Red River Delta and the South East, had a higher probability of escaping poverty.

Tarp et al. (2002) appraise the consequences of Vietnam's shifting import and export patterns and argue that trade and other reforms will not realize their full potential for all Vietnamese households in the absence of deliberately corrective fiscal measures. Further, Le and Winters (2001) argue that there is an imbalance between aid which promotes economic growth and aid which directly targets the poor. They also argue that aid is not regionally directed in a manner conducive to poverty alleviation and is urban-biased.

All of the above observations motivate us to examine the spatial dimension of trade policy incidence and its implications for poverty. Changes in the spatial distribution of poverty have some practical importance as well, because such changes alter the efficient geographical targeting scheme. However, previous studies gave little guidance about how to shift resources in response to a changing macroeconomic environment. In this study, we show which part of the country is least likely to benefit from trade liberalization. In addition to contributing to Vietnam evidence to the more general debate on globalization and poverty, these results provide guidance for those policymakers who want to formulate geographic targeting policies for poverty reduction. 
We combine four different data sets in this study. First, the information required is a socioeconomic data set. We use the VLSS 1997-98 data set, which contains a wide array of microeconomic data, such as information on housing, employment, household enterprises, income and asset holdings. The survey was conducted by Vietnam's General Statistical Office (GSO). The United Nations Development Programme (UNDP) and the Swedish International Development Agency (SIDA) provided financial assistance whereas the World Bank provided technical assistance. The sample of VLSS 1997-98 is nationally representative and stratified into two groups representing urban and rural areas. The number of households in the sample is, 4270 in rural areas and, 1730 in urban areas (World Bank, 2001).

Second, we used the 1999 Population and Housing Census. The census was carried out by the GSO with financial and technical support from the United Nations Population Fund and UNDP. The census data set contains individual-level information such as age, sex, education and occupation as well as household-level information such as housing characteristics and asset holdings. It also contains the employment status of each individual. We used a 33 per cent sample of the census, which contains records for every third household organized by an administrative unit. The sample selection was made by GSO. The sample includes 5,553,811 households and 25,447,457 individuals.

Third, we use a compilation of geographic variables. These include elevation, precipitation, soil quality, sunshine duration and access to cities. Some of the variables are based on remotely sensed data, while others are mean values from community-level data. The geographic variables can be merged into the census and the survey by the administrative codes.

Finally, we use the 2000 Social Accounting Matrix (SAM) for Vietnam as a core building block of the CGE model, representing 97 production activities and commodities, 13 factors of production (labour and capital), 5 household types, and 94 international trading partners. The aggregated version of SAM includes aggregate wage 
incomes for eight labour segments defined by male/female, skilled/unskilled and urban/rural. It also includes the non-wage household incomes for urban and rural areas.

Let us now briefly discuss the measurement of poverty. In the standard analysis of socioeconomic survey data such as the VLSS, poor people are defined as those living in households whose per capita consumption is below the poverty line. Consumption has several advantages over other income measures and proxies. First, it is a money metric measure and easy to interpret. Second, it does not vary in the short run, unlike income. Despite these advantages of consumption, however, we use the per capita income measure for the household. This is because we need to aggregate the information in the VLSS data set in a way that is consistent with the SAM and to allow the individuals in the microsimulation to switch their employment status. We shall come back to the details of this point in the next section.

To calculate the income measures, we first identified the employment status of all the individuals in the potential labour force. We regarded individuals aged between 15 and 64 who are not students or invalid as being part of the potential labour force. We then classified those in the potential labour force into the following three categories: 1) wage earners, 2) self-employed and 3) not-working. Wage earners are those who earn any wage income and do not engage in the household enterprise. Self-employed people are those who engage in at least one of their household enterprises. All the other people are defined as not-working. Employment status is available in both the census and survey data sets.

We calculated wage incomes for wage-earners and non-wage household incomes for all the households on the annual basis using the VLSS data set. To find the non-wage household income, we calculated the sum of incomes from each household enterprise, asset incomes and transfers. We summed all the wage incomes in the household and the non-wage household income, and divided by the household size to arrive at the per capita income measure. To remove the seasonal and regional price variations, we apply the same price deflator as the one used to calculate consumption poverty. 
It is useful to look at how income and consumption measures differ. Table 1 provides some summary statistics for the per capita consumption and income measures. The national-level mean of the per capita consumption is about 13 per cent lower than the corresponding figure for the per capita income, while the standard deviation for the consumption is about half as that for the income.

\section{[Table 1 about here]}

The comparison of column 1 and column 5 gives the differences in mean per capita income and consumption at the regional level, at which the VLSS is representative. The number of households and population share of each region are reported in Column 9 and Column 10. At the regional level, income and consumption exhibit a very similar pattern and their correlation is higher than 0.98. Even at the individual level, the correlation is as high as 0.64 .

We can also compare the consumption-based poverty $\left(P_{0}^{C}\right)$ and income-based poverty $\left(P_{0}^{I}\right)$ measures. To make the consumption-based and income-based poverty measures comparable, we set the poverty line so that they have the same poverty rates of 37.4 per cent (see World Bank, 2001). We set the poverty line at VND 3,452.06 per day per capita. $^{2}$

The poverty rates are identical by construction, but there may be regional differences. This can be checked by looking at Columns 3 and 7 . It turns out that the spatial distributions of income and consumption poverty are reasonably close, though there are two notable differences. First, in the Red River Delta, the income poverty is much higher than the consumption poverty. On the other hand, in Mekong River, the consumption poverty is much higher than the income poverty rate. Overall, income and consumption measures show a similar pattern of spatial distribution, though income measure is on average a much noisier measure than consumption. 


\section{METHODOLOGY}

Estimation of poverty and other economic indicators at the level of small geographic areas is generally constrained by the availability of representative data. In Vietnam, the VLSS data do not support reliable poverty measures even at the provincial level because the sampling strata are more aggregated than provinces. However, the small area estimation (SAE) developed by Elbers et al. (2002, 2003) has enabled us to reliably estimate measures of poverty and inequality at a spatially disaggregated level.

The SAE approach typically combines survey and census data source. Consumption or income regression models are estimated with the survey data set. The regressors contain only the variables in the geographic data set or the variables that also appear in the census data set. The left-handside variable is then imputed to each census record and aggregated to obtain poverty and inequality measures of interest. Using a MonteCarlo simulation technique provided by Elbers et al. (2002, 2003), imputation and aggregation are done repeatedly to develop point estimates of poverty and inequality measures as well as their associated standard errors.

The SAE estimates of poverty rates are often plotted on a map, and conventionally named a poverty map. The poverty map is visually immediate and popular among policy-makers and other stakeholders. The SAE estimates can support geographic targeting policies to focus assistance on the neediest people. Such estimates can also be used to analyze the spatial relationship between poverty and geographic variables. In Vietnam, Minot (2000) created a poverty map using the VLSS 1992-93 and the Agricultural Census for 1994 with the probit model. Minot et al. (2003) have produced consumption-based small-area estimates of poverty and inequality using the VLSS 1997-98 and the Population Census for 1999.

Although the SAE estimates are useful, limitations remain. Since existing SAE techniques can only generate static maps, they do not reveal how the poverty map will

2 According to the World Development Indicators, the Purchasing Power Parity conversion factor (for 1998) was USD $1=$ VND 2,673. 
change as a result of changing macroeconomic environment. Hence, the geographic targeting policy based on the static SAE estimates may be inappropriate after Vietnam's accession to the WTO. To overcome the static nature of poverty mapping, this study combines the SAE method with an integrated microsimulation-CGE model.

This paper uses an CGE approach to elucidating linkages between trade and poverty, and joins a large and growing literature on this subject. Beginning with Adelman and Robinson's work on Korean growth in the 1970s, CGEs have found application to trade, growth, and poverty issues in scores of developing countries. A complete survey of these contributions is outside the scope of this paper, but readers can find an extensive set of applications as well as literature synthesis in a recent volume by Hertel and Winters (2006).

The present approach represents a recent line of CGE techniques that integrate traditional economywide models with microeconomic simulation menthods calibrated to household survey and census data. This significantly increase the resolution of economic analysis and captures essential structural heterogeneity. Integrated microsimulation-CGE methods were first proposed by Bourguignon et al. (2005). They apply their method to analyze the impact of a change in the foreign trade balance before the Asian financial crisis in Indonesia. Unlike standard CGE models, an integrated microsimulation-CGE model explicitly takes account of detailed heterogeneity among households and linkages between different sectors of the economy. It can be used to analyze a range of national level policies such as trade and taxation as well as macroeconomic shocks.

While the integrated microsimulation-CGE model allows us to identify heterogeneous impacts of trade liberalization, it provides policy makers with little useful information to support geographical targeting after or in coordination with trade policy. This is because the spatial disaggregation of the SAM is usually very limited, and thus the CGE model allows very limited spatial disaggregation. It is only by embedding the SAE method in an integrated microsimulation-CGE model that we can adequately 
represent the spatial distribution of poverty after trade liberalization and in response to complementary policies. ${ }^{3}$

As noted before, for present discussion we use per capita household income as a measure of welfare. We find a scaling factor for each segment of the economy so that non-wage household income, individual wages and labour supply in the survey sum up to the corresponding macroeconomic figures in the CGE. Formally, this is equivalent to solving for scaling factors $S C$ in the following equations:

$$
\begin{gathered}
W G I_{l}=S C_{l}^{W G I} \sum_{\{(h, i): f(h, i)=l\}} \mathbf{w}_{h i} \\
N W I_{m}=S C_{m}^{N W I} \sum_{\{h: g(h)=m\}} \mathbf{y}_{h} \\
T N W_{l}=S C_{l}^{T N W} \sum_{\{(h, i): f(h, i)=l\}} \mathbf{I W}_{h i} \\
T N S_{l}=S C_{l}^{T N S} \sum_{\{(h, i): f(h, i)=l\}} \mathbf{I S}_{h i}
\end{gathered}
$$

In $\mathrm{Eq}(1)-\mathrm{Eq}(4)$, the subscript $l$ is the labour segment, which is a combination of skilled/unskilled, male/female and urban/rural. The subscript $m$ represents the household segment, which is urban/rural. The left-hand-side variables $W G I, N W I, T N W$ and TNS are aggregate wage income, non-wage income, the total number of wage earners and total number of self-employed individuals in the SAM. w, y, IW and IS are respectively the individual wage income, non-wage household income, indicator variable for being a wage-earner, and indicator variable for being a self-employed individual. The function $f(h, i)$ maps the individual $i$ in household $h$ to the labour

\footnotetext{
3 If we are interested in the impacts of price changes in a particular sector on the spatial distribution of poverty, we could use a partial equilibrium model. We could, for example, predict nominal consumption using the SAE method and then estimate the changes in real consumption by exploiting the heterogeneity in consumption pattern across the country.
} 
segment the individual belongs to. The function $g(\cdot)$ maps household $h$ to urban or rural area. $^{4}$

To elucidate the spatial incidence of trade liberalization, we first estimate poverty measures for small areas before the trade liberalization. This step is conceptually similar to the standard SAE approach. The difference is that we use multiple equations for this estimation. We assume that $\mathbf{w}, \mathbf{y}, \mathbf{I W}$ and IS are related to individual or household characteristics through following equations:

$$
\begin{aligned}
& \log \mathbf{w}_{h i}=\alpha_{g(h, i)}+\mathbf{x}_{h i} \beta_{g(h, i)}+\mu_{h i} \\
& \log \mathbf{y}_{h}=\gamma_{f(h)}+\mathbf{z}_{h} \delta_{f(h)}+\mathbf{S}_{h} \lambda_{f(h)}+\eta_{h} \\
& \mathbf{I W}_{h i}=\operatorname{Ind}\left(a_{g(h, i)}^{w}+\mathbf{v}_{h i} b_{g(h, i)}^{w}+u_{h i}^{w}>\sup \left(u_{h i}^{n}, a_{g(h, i)}^{s}+\mathbf{v}_{h i} b_{g(h, i)}^{s}+u_{h i}^{s}\right)\right) \\
& \mathbf{I S}_{h i}=\operatorname{Ind}\left(a_{g(h, i)}^{s}+\mathbf{v}_{h i} b_{g(h, i)}^{s}+u_{h i}^{s}>\sup \left(u_{h i}^{n}, a_{g(h, i)}^{w}+\mathbf{v}_{h i} b_{g(h, i)}^{w}+u_{h i}^{w}\right)\right) \\
& \mathbf{S}_{h} \equiv \sum_{i \in \mathscr{S}_{h}} \mathbf{I} \mathbf{S}_{h i} \\
& \mathbf{H}_{h} \equiv \frac{1}{\mathbf{N}_{h}}\left(\mathbf{y}_{h}+\sum_{\left\{i: i \in \mathscr{S}_{h}, \mathbf{I} \mathbf{W}_{h i}=1\right\}} \mathbf{w}_{h i}\right)
\end{aligned}
$$

In $\operatorname{Eq}(5)$, individual logarithmic wage is related to individual characteristics $\mathbf{x}_{h i}{ }^{i}{ }^{5} \mathrm{In}$ $\mathrm{Eq}(6)$, logarithmic household non-wage income is related to household characteristics $\mathbf{z}_{h}$ and the number of self-employed individuals in the household $\mathbf{S}_{h}$. Labour supply is modeled by $\operatorname{Eq}(7)$ and $\operatorname{Eq}(8)$, where individual characteristics $\mathbf{v}_{h i}$ are related to the 'utility' from being a wage-earner and self-employed. $u_{h i}^{n}$ can be considered the random reservation utility for working. We assume that the error terms $\mu_{h i}, \eta_{h}, u_{h i}^{w}, u_{h i}^{s}$

4 An alternative approach is to calibrate the sum so that these equations hold without the scaling factor. Either way, we have to make somewhat arbitrary adjustments. This is unavoidable because the sum of the survey observations is not necessarily consistent with the SAM. Note that we are only concerned about the ratios of these macroeconomic indicators before and after Vietnam's accession to the WTO.

$5 \mathbf{x}, \mathbf{z}$ and $\mathbf{v}$ are expressed in a row vector format. 
and $u_{h i}^{n}$ are independent. Furthermore, we assume that $\mu_{h i}$ follows a normal distribution with mean zero and variance $\sigma_{\mu}^{2}$, and $\eta_{h}$ a normal distribution with mean zero and variance $\sigma_{\eta}^{2}$. We also assume that $u_{h i}^{w}, u_{h i}^{s}$ and $u_{h i}^{n}$ follow an identical Gumbel distribution.

$\mathrm{Eq}(9)$ simply states that the number of self-employed is the sum of $\mathbf{I S}_{h i}$ over the set of individuals $\mathscr{I}_{h}$ within household $h$. The per capita household income $\mathbf{H}_{h}$ is, of course, the sum of wage and non-wage income earned by the household members divided by the household size $\mathbf{N}_{h}$, as it is defined in $\mathrm{Eq}(10)$.

As with the standard SAE, we consider above equations as a predictive model, using a rich set of regressors to explain the variation of left-hand-side variables in $\mathrm{Eq}(5), \mathrm{Eq}(6)$, $\mathrm{Eq}(7)$ and $\mathrm{Eq}(8)$. However, regressors can only include the variables shared by the census and the survey.

We first estimate the parameters of the equations above. Only the survey data set is used at this stage. We run OLS to estimate $\mathrm{Eq}(5)$ and $\mathrm{Eq}(6)$, whereas we use a multinomial logit model to jointly estimate $\mathrm{Eq}(7)$ and $\mathrm{Eq}(8)$. Therefore, we estimate the regression coefficients $\alpha, \beta, \gamma, \delta, \lambda, a^{w}, a^{s}, b^{w}$ and $b^{s}$ and their associated variancecovariance matrix adjusted for the clustering of the survey sample. We also estimate the distribution parameters $\sigma_{\mu}^{2}$ and $\sigma_{\eta}^{2}$. We shall denote the estimates with a hat (e.g. $\hat{\alpha})$.

As with Elbers et al. (2003), we estimate left-hand-side variables in $\mathrm{Eq}(5)-\mathrm{Eq}(10)$ for each census record repeated by a Monte-Carlo simulation. To allow for the error in the estimated regression coefficients, we draw regression coefficients from a multinomial normal distribution in each round of the simulation. We shall denote the drawn coefficients by superscript $(r)$ to specify the $r$-th round of the simulation. In addition, we draw error terms for each census record. For example, the estimate of wage income $\hat{\mathbf{w}}_{h i}^{(r)}$ for (census) household $h$ and individual $i$ in the $r$-th round is calculated as follows: 


$$
\hat{\mathbf{w}}_{h i}^{(r)}=\exp \left(\hat{\alpha}_{g(h, i)}^{(r)}+\mathbf{x}_{h i} \hat{\beta}_{g(h, i)}^{(r)}+\hat{\mu}_{h i}^{(r)}\right)
$$

where $\mathbf{x}_{h i}$ comes from the census data set and $\hat{\mu}_{h i}^{(r)}$ is drawn from the normal distribution with mean zero and variance $\hat{\sigma}_{\mu}^{2}$. Note that we know the employment status of each individual in the census and thus we observe $\mathbf{I W}_{h i}$ and $\mathbf{I S}_{h i}$. However, we still need to draw $\hat{u}_{h i}^{w,(r)}, \hat{u}_{h i}^{s,(r)}$ and $\hat{u}_{h i}^{n,(r)}$ for the later simulation. We can draw $\hat{u}_{h i}^{n,(r)}$ from the Gumbel distribution. $\hat{u}_{h i}^{w,(r)}$ and $\hat{u}_{h i}^{s,(r)}$ must be drawn conditionally on the observed dummy variables for the employment status $\mathbf{I W}_{h i}, \mathbf{I S}_{h i}$ as well as the drawn error term $\hat{u}_{h i}^{n,(r)}$ in order to be consistent with the observed employment status.

It is straightforward to impute household non-wage income using $\mathrm{Eq}(6)$. $\mathrm{By} \mathrm{Eq}(10)$, we get an estimate of the per capita household income $\hat{\mathbf{H}}_{h}^{(r)}$. We can then obtain aggregate welfare measures such as the FGT measure of poverty, see Foster et al. (1984). Letting $\mathscr{A F}_{p}$ be the set of households in province $p$ and $z$ be the poverty line, the head count poverty rate $P_{p}^{(r)}$ in province $p$ for the $r$-th simulation can be written as follows:

$$
P_{p}^{(r)}=\frac{\sum_{h \in \mathscr{H}_{p}} \operatorname{Ind}\left(\hat{\mathbf{H}}_{h}^{(r)}<z\right) \cdot \mathbf{N}_{h}}{\sum_{h \in \mathscr{P}_{p}} \mathbf{N}_{h}}
$$

Taking the average and standard deviation across simulations, we arrive at the point estimate of poverty rate for province $p$ and its associated standard error. The aggregate welfare estimates derived in this manner serve as the baseline information for each province or any geographic units. We shall refer to the poverty estimates before the trade liberalization created in this way as the ex ante poverty estimates.

The next step is to simulate how much change would occur across different sectors of the economy. As with Bourguignon et al. (2005), we need to find error terms for each survey record. It is straightforward to find $\mu_{h i}$ and $\eta_{h}$, because they are just the observed value minus the predicted value. When the wage data is missing, $\mu$ is drawn from the normal distribution. We also draw $\hat{u}_{h i}^{w}, \hat{u}_{h i}^{s}$ and $\hat{u}_{h i}^{n}$ from a Gumbel distribution in a way consistent with the observed employment status. Therefore, combining Eq(1)$\mathrm{Eq}(4)$ and $\mathrm{Eq}(5)-\mathrm{Eq}(8)$, we have the following relationship: 


$$
\begin{aligned}
& W G I_{l}=S C_{l}^{W G I} \sum_{\{(h, i): g(h, i)=l\}} \exp \left(\hat{\alpha}_{l}+\mathbf{x}_{h i} \hat{\beta}_{l}+\hat{\mu}_{h i}\right) \\
& N W I_{m}=S C_{m}^{N W I} \sum_{\{h: f(h)=m\}} \exp \left(\hat{\gamma}_{m}+\mathbf{z}_{h} \hat{\delta}_{m}+\mathbf{S}_{h} \hat{\lambda}_{m}+\hat{\eta}_{h}\right) \\
& T N W_{l}=S C_{l}^{T N W} \sum_{\{(h, i): g(h, i)=l\}} \operatorname{Ind}\left(\hat{a}_{l}^{w}+\mathbf{v}_{h i} \hat{b}_{l}^{w}+\hat{u}_{h i}^{w}>\sup \left(\hat{u}_{h i}^{n}, \hat{a}_{l}^{s}+\mathbf{v}_{h i} \hat{b}_{l}^{s}+\hat{u}_{h i}^{s}\right)\right) \\
& T N S_{l}=S C_{l}^{T N S} \sum_{\{(h, i): g(h, i)=l\}} \operatorname{Ind}\left(\hat{a}_{l}^{s}+\mathbf{v}_{h i} \hat{b}_{l}^{s}+\hat{u}_{h i}^{s}>\sup \left(\hat{u}_{h i}^{n}, \hat{a}_{l}^{w}+\mathbf{v}_{h i} \hat{b}_{l}^{w}+\hat{u}_{h i}^{w}\right)\right)
\end{aligned}
$$

The macroeconomic CGE provides us with aggregate wage and non-wage household incomes in each segment of the economy, as well as the aggregate labour supply from wage-earners and self-employed individuals. In other words, we obtain aggregate macroeconomic account after the trade liberalization, which we shall denote with tilde (e.g. $W G I_{l}$ ). To maintain the consistency between the left-hand-side and the righthand-side of the system of equations above, we need to change at least one of the parameters in each equation. Following the method outlined by Bourguignon et al. (2005), we assume that the macroeconomic changes are channelled through the intercepts in the above equations. Bourguignon et al. (2005) show that this assumption implies a neutrality of the change with regard to individual or household characteristics. For example, the ratio of wages in the same labour segment will not be altered before and after the trade liberalization. Similarly, the relative change in the probability that an individual has a certain occupation depends only on the initial ex ante probability of the various occupational choices, and not on individual characteristics. The problem we face is therefore equivalent to solving for the adjustment coefficients $\triangle \alpha, \Delta \gamma, \Delta a^{w}$ and $\Delta a^{s}$, which are the difference in ex ante and ex post intercepts, in the following equations:

$$
\begin{aligned}
& W G I_{l}=S C_{l}^{W G I} \sum_{\{(h, i): g(h, i)=l\}} \exp \left(\Delta \alpha_{l}+\hat{\alpha}_{l}+\mathbf{x}_{h i} \hat{\beta}_{l}+\hat{\mu}_{h i}\right) \\
& \Delta W I_{m}=S C_{m}^{N W I} \sum_{\{h: f(h)=m\}} \exp \left(\Delta \gamma_{m}+\hat{\gamma}_{m}+\mathbf{z}_{h} \hat{\delta}_{m}+\mathbf{S}_{h} \hat{\lambda}_{m}+\hat{\eta}_{h}\right)
\end{aligned}
$$




$$
\begin{aligned}
& \overparen{T N} W_{l}=S C_{l}^{T N W} \sum_{\{(h, i): g(h, i)=l\}} \operatorname{Ind}\left(\triangle a_{l}^{w}+\hat{a}_{l}^{w}+\mathbf{v}_{h i} \hat{b}_{l}^{w}+\hat{u}_{h i}^{w}>\sup \left(\hat{u}_{h i}^{n}, \Delta a_{l}^{s}+\hat{a}_{l}^{s}+\mathbf{v}_{h i} \hat{b}_{l}^{s}+\hat{u}_{h i}^{s}\right)\right) \\
& \operatorname{TNS} S_{l}=S C_{l}^{T N S} \sum_{\{(h, i): g(h, i)=l\}} \operatorname{Ind}\left(\Delta a_{l}^{s}+\hat{a}_{l}^{s}+\mathbf{v}_{h i} \hat{b}_{l}^{s}+\hat{u}_{h i}^{s}>\sup \left(\hat{u}_{h i}^{n}, \Delta a_{l}^{w}+\hat{a}_{l}^{w}+\mathbf{v}_{h i} \hat{b}_{l}^{w}+\hat{u}_{h i}^{w}\right)\right)
\end{aligned}
$$

After finding the adjustment coefficients, we can again impute individual wage income, the 'utility' of each individual, and the non-wage household income. This time, however, we include the adjustment coefficients. For example, we replace $\hat{\alpha}_{l}^{(r)}$ by $\Delta \alpha_{l}+\hat{\alpha}_{l}^{(r)}$ in $\operatorname{Eq}(11)$. It should be noted by that the ex post employment status may be different from the observed ex ante employment status, which in turn affects the non-wage household income. Once we have individual wage income and non-wage household income, we can calculate the per capita income for each census household as well as the poverty status in each round of the simulation. By aggregating geographically, we can obtain the poverty estimates after trade liberalization, or the ex post poverty estimates.

\section{RESULTS}

\subsection{Macroeconomic CGE}

For economy-wide analysis, a macroeconomic CGE for Vietnam was calibrated to the new 2000 Vietnam SAM for a 'business as usual' baseline. This reference scenario was then used to evaluate comparative static experiments provided by GTAP global liberalization results. To implement the latter, we obtained data from GTAP on induced price and external demand changes for the purpose of re-calibrating Vietnamese exports against downward sloping external demand functions. Finally, we assume the so-called Hertel-Keeney medium-run closure. That is, all factors are fully employed before and after experiments, labour and capital are mobile across sectors, but we maintain a specific factor (land) in agriculture. There is no imperfect competition nor economies of scale or dynamic gains from trade (Hertel, 1997). 
In this paper, we compare three counterfactual scenarios to the baseline, which we call Unilateral Liberalization (UL), Full Liberalization (FL) and Doha Special and Differential Treatment (DSDT) ${ }^{6}$. The baseline scenario corresponds to the ex ante case. In the UL scenario, we assume that Vietnam's last offer to the WTO is accepted, the country joins the organization. We assume that Vietnam removes all import tariffs and export subsidies. However, Vietnam's trading partners maintain baseline protection levels with respect to this country and all others. In this case, the benefits of fuller participation in the international economy are severely limited by Vietnam's inability to penetrate new markets, and the gains of domestic price reform have more limited impact on the growth of income.

The FL scenario includes the same external policy, but embeds this into a larger agenda. This scenario is calibrated to protection rates from the Vietnamese WTO offer, but further assumes that Vietnamese export prices and demand patterns shift according to consensus estimates for a FL scenario obtained using the GTAP global trade database and model. This scenario would greatly expand export opportunities for Vietnam, allowing it to take fuller advantage of efficiency gains arising from border price reforms. In the DSDT scenario, we also assume that Vietnam removes all exports subsidies, but it preserves the Special and Differential Treatment of developing countries. As such, domestic support and tariffs are reduced but not eliminated.

Aggregate comparative static results for these counterfactuals are presented in Table 2. In terms of aggregate growth, these scenarios are generally consistent with intuition. In particular, FL is the biggest stimulus to Vietnam, followed by UL and DSDT. Real GDP rises moderately under UL and FL scenarios, but slightly declines under DSDT scenario. FL also brings about a higher level of real consumption than UL and DSDT do. This is not only a result of greater trade stimulus but also a result of improved terms of trade. At the other extreme, removing export support in the DSDT scenario induces an adverse terms of trade effect, making Viet Nam exporters less competitive and more than offsetting efficiency gains from tariff removal. Given existing distortions

\footnotetext{
6 The policy context for the DSDT scenario is discussed extensively in Hertel and Winters (2006).
} 
elsewhere in the trading system, a piecemeal approach like DSDT would be inferior to even the status quo.

[Table 2 about here]

Our CGE results show that textiles, technology, and machinery sectors expand significantly, accompanied by construction, and trade and transport services, while the agricultural sector remains prominent as shown in Table 3. More fundamentally, these results begin to reveal the mechanisms by which external liberalization can affect poverty and inequality in Vietnam. Like many developing countries, Vietnam's poor majority are farmers living at or near the subsistence level. Their assets are generally limited to labour, small land holdings of uncertain quality and livestock. In the Asian context, external liberalization has generally provided the most direct growth impetus to urban populations through expansion of light, intermediate, and heavy industrial activities. The majority of the rural poor have two channels by which they can participate in urban based growth, migration and marketing of food products. The comparative static model used here does not model the former, so we confine our attention to changing income opportunities.

The sectoral results of Table 3 presage our subsequent poverty analysis. The most important difference between the scenarios in this context has to do with food prices and domestic output responses. Under the UL scenario, food prices are suppressed by import liberalization and farmers suffer directly and indirectly. In the case of FL, all primary food prices rise and farm output and income respond accordingly. Clearly, a low income agrarian country like Vietnam needs to see significant agricultural returns from any multi-lateral trade agreement, if its poor rural majority are to benefit in the short or medium term.

[Table 3 about here] 


\subsection{Changes in poverty rates after trade liberalization}

As noted in the previous section, our analysis starts by looking at the spatial distribution of poverty under the Baseline (ex ante) scenario. We estimated relevant parameters in $\mathrm{Eq}(5)-\mathrm{Eq}(8)$ using the VLSS data set.

For $\operatorname{Eq}(5)$, we simply ran OLS for each wage-earner of the eight labour segments to find coefficients. The $R^{2}$ statistic varied from 0.24 to 0.42 , depending on the labour segment. For Eq(6), we ran OLS of logarithmic non-wage income for urban and rural areas, capturing about 35 per cent and 38 per cent of variations. There are about 1.2 per cent of households without any non-wage income, and they were excluded from the estimation. Multinomial logit regressions were run to estimate $\mathrm{Eq}(7)$ and $\mathrm{Eq}(8)$ for each labour segment. We were able to predict 73 per cent of the individuals correctly after applying the relevant weights. Detailed estimation results are reported in the Appendix.

The macroeconomic CGE results also gives us the aggregate wage income for each combination of skilled/unskilled, male/female and urban/rural as well as the non-wage income for rural and urban households. This allows us to calculate the adjustment coefficients by solving $\mathrm{Eq}(13)-\mathrm{Eq}(16)$. The adjustment coefficients for each scenario are also reported in the Appendix.

We first imputed the household income for each census record for each round of the Monte-Carlo simulation without applying the adjustment coefficients. We then calculated poverty rates for each province using $\mathrm{Eq}(12)$ and plotted them on a map as shown in Figure 1, which we shall call the baseline map. The maximum, minimum and average standard error for the provincial-level estimate of poverty rate were 11.6 per cent, 0.4 per cent and 2.1 per cent respectively. Thus, while there are a few provinces with quite high-levels of standard errors, provincial-level estimates are on average accurate enough to justify this presentation.

To see how our estimates correspond to others in the literature, we first calculated the poverty rate for Vietnam. The point estimate and its associated standard error were 34.6 per cent and 0.7 per cent respectively. The difference between this estimate and the 
survey-only estimate is not significant. However, the gap is not as small as one would usually find in the standard small-area estimation. This is possibly because we need to estimate many more equations than the standard method. We also plotted the provincial-level estimates of our income poverty rates against the provincial-level consumption poverty rates calculated by Minot et al. (2003). There is a moderately strong correlation between the two measures with the correlation coefficient of 0.4. Overall, our baseline estimates of poverty seem reasonable.

In order to see how income poverty changes after Vietnam's accession to the WTO under various scenarios, we applied the adjustment coefficients and re-calculated the household income for each census household and for each scenario. Then, we recalculated the poverty rates for each province. This yields ex post estimates of poverty. The ex post estimates of poverty in Vietnam has decreased by 0.8 per cent and 6.8 per cent under the UL and FL scenarios respectively. However, under the DSDT scenarios, the national poverty rate increased by 0.6 per cent. Again, we see that the FL helps reduce poverty most.

[Figure 1 about here]

[Figure 2 about here]

We also looked at changes in poverty rates at the provincial-level. Figure 3 shows the spatial incidence of trade policy under the UL scenario. Figure 4 and Figure 5 are for the FL and DSDT scenarios respectively. In each map, lighter colours represent higher levels of improvement or lower levels of aggravation in terms of the provincial-level poverty rate. In other words, the lighter colours get relatively more beneficial impacts from trade liberalization.

[Figure 3 about here]

[Figure 4 about here] 
[Figure 5 about here]

Three salient points deserve emphasis here. First, the magnitude of the impact of trade policy on poverty can vary quite substantially across the country. Under the FL scenario, one province achieves 14.3 per cent lower headcount poverty, while another province only achieves 2.4 per cent reduction. This difference is adducible to differences in the initial distribution of income, as well as heterogeneity in the composition of households and individuals. Under the UL and DSDT scenarios, spatial differences in absolute terms are much smaller because the changes in aggregates are also smaller.

Second, the trade liberalization appears to be consistent with poverty reduction overall. The correlations between the ex ante poverty rates and the changes in poverty after trade liberalization at the provincial level are $-0.26,-0.71$ and -0.60 for the UL, FL and DSDT scenarios. This suggests that the FL scenario not only achieves the largest poverty reduction among all the scenarios, but helps the most impoverished areas. This point may be more clearly seen from Figure 6. It plots the ex ante poverty rate against the change in poverty rate under the FL scenario. It shows that the reductions in poverty rate are generally higher for the areas that are poor ex ante. On the other hand, the change in poverty rates varies substantially among the provinces with similar ex ante poverty rates.

[Figure 6 about here]

The third point to note is that the spatial pattern is similar across all the scenarios considered. We generally see greater improvement (or less adversity in case of the DSDT scenario) in poverty along the coastal areas, whereas the northwest of Vietnam and the Lao-Vietnam border areas will not see much improvement. On the other hand, the lagging northwestern provinces are of particular concern because the poverty rates are already high there. It might therefore be desirable to target further assistance to this region.

So far, we have ignored changes in the consumer prices. To account for this, we divided the poverty line by the ex post consumer price index. This treatment is 
rudimentary because we cannot capture potential differences in the changes in consumer prices across the country. However, we can estimate the magnitude of price effects in aggregate terms. If we account the changes in the consumer prices, there will be additional real benefits of 1.4 per cent and 0.3 per cent for the UL and FL scenarios in poverty reduction. Under the DSDT scenario, the increase in poverty rate will be reduced to just 0.4 per cent.

\section{CONCLUSION}

This study explored the spatial dimension of poverty associated with Vietnam's accession to the WTO. While Vietnam as a whole is likely to benefit from the accession, the degree and spatial composition of poverty reduction across the country is more ambiguous. The main constraint in this context is estimating the spatial incidence of structural adjustments arising from trade liberalization. By combining the integrated microsimulation-CGE model with the small area estimation technique, we were able to overcome this constraint.

Our simulation results show that aggregate poverty will decrease when Vietnam removes all import tariffs and export subsidies. The amount of improvement will be even larger when other countries also remove tariffs against Vietnamese products. On the other hand, the DSDT scenario leads to a slight increase in poverty.

As Figures 3-5 show, the impacts of Vietnam's accession to the WTO are spatially heterogeneous. The heterogeneity is particularly large under the FL scenario. Our study suggests that poor provinces in the northwestern regions may benefit little from trade liberalization. This is of concern from the view point of spatial equity within the country. Further, spatial heterogeneity in poverty reduction affects the efficiency of the targeting policies. Thus, our estimates provide guidance for policy-makers to develop efficient targeting policies that complement trade liberalization policies. Such policies 
would conserve public resources and prevents poor areas from lagging further behind national growth.

Of course, policy application of the modelling exercise must be done with great caution as modelling necessariliy involves abstraction and simplification. For example, SAE method requires the stability of parameter values in the sense that the relationship between the left-hand-side variables and right-hand-side variables holds before and after the trade liberalization. The CGE model requires a number of simplifying assumptions about the interaction of various economic sectors. Further, our estimates do not take into account impacts other than trade liberalization policies. Given these, our estimates should not be the sole basis for choosing the target areas. Instead, policy makers could use our estimates as initial search points to determine the target areas.

The method we developed in this study has relevance to many other economic policy issues. For example, we can simulate the spatial incidence of exogenous price shocks or hypothetical taxes and other fiscal instruments. While the amount of computation and data requirements (survey, census, and social accounting matrix) may be significant, there are many countries that already possess such resources. Geographic targeting is already widely used in developing countries, but it is often formulated independently of their macroeconomic policies. Our method of combining the integrated microsimulation-CGE model with small-area estimation provides an opportunity for linking the two to achieve a more complete set of microeconomic and macroeconomic objectives.

\section{REFERENCES}

Anderson, K. (1999). Vietnam's Transforming Economy and WTO Accession. Singapore: Institute of Southeast Asian Studies.

Bhagwati, J., and T. N. Srinivasan (2002). 'Trade and Poverty in Poor Countries'. American Economic Review, 92(2): 180-183.

Bourguignon, F., A. Robilliard, and S. Robinson (2005.) 'Representative Versus Real Households in the Macroeconomic Modeling of Inequality', in T. J. Kehoe, 
T. N. Srinivasan, and J. Whalley (eds), Frontiers in Applied General Equilibrium Modelling. Cambridge: Cambridge University Press.

Dollar, D., and A. Kraay (2002). 'Growth is Good for the Poor'. Journal of Economic Growth, 7(3): 195-225.

— (2004). 'Trade, growth, and poverty'. Economic Journal, 114: F22-F49.

Elbers, C., J. O. Lanjouw, and P. Lanjouw (2002). 'Welfare in Villages and Towns: Micro-level Estimation of Poverty and Inequality.' Working Paper 2911. Washington, DC: World Bank.

— (2003). 'Micro-level Estimation of Poverty and Inequality'. Econometrica, 71(1): $355-364$.

Foster, J., J. Greer, and E. Thorbecke (1984). 'A Class of Decomposable Poverty Measures'. Econometrica, 52(3): 761-765.

Fukase, E., and W. Martin (2000). 'The Effects of the United States Granting MFN Status to Vietnam'. Weltwirtschaftliches Archiv, 136(2): 539-59.

_ (2001.) 'A Quantitative Evaluation of Vietnam's Accession to the ASEAN Free Trade Area'. Journal of Economic Integration, 16(4): 545-567.

Glewwe, P., M. Gragnolati, and H. Zaman (2002). 'Who gained from Vietnam's boom in the 1990s?'. Economic Development and Cultural Change, 50(4): 773-792.

Harrison, G. W., T. F. Rutherford, and D. G. Tarr (2003). 'Trade Liberalization, Poverty and Efficient Equity'. Journal of Development Economics, 71: 97-128.

Heng, M. T., and V. Gayathri (2004). 'Impact of Regional Trade Liberalization on Emerging Economies: The Case of Vietnam'. ASEAN Economic Bulletin, 21(2): $167-182$.

Hertel, T. W. (1997) (ed.). Global Trade Analysis: Modeling and Applications. Cambridge: Cambridge University Press. 
Hertel, T.W., and L. A Winters (eds.) (2006). Poverty and The WTO: Impacts of the Doha Development Agenda. World Bank, Washington, 334pp.

Jenkins, R. (2004). 'Vietnam in the Global Economy: Trade, Employment and Poverty'. Journal of International Development, 16: 13-28.

Jensen, H. T., and F. Tarp (2005). 'Trade Liberalization and Spatial Inequality: A Methodological Innovation in a Vietnamese Perspective'. Review of Development Economics, 9(1): 69-86.

Kanbur, R. (2001). 'Economic Policy, Distribution and Poverty: The Nature of Disagreements'. World Development, 29(6): 1083-1094.

Krueger, A. O. (1998). 'Why Trade Liberalisation is Good for Growth'. Economic Journal, 108(450): 1513-1522.

Le, T. H., and P. Winters (2001). 'Aid Policies and Poverty Alleviation: The Case of Vietnam'. Asia-Pacific Development Journal, 8(2): 27-44.

Litchfield, J., and P. Justino (2004). 'Welfare in Vietnam during the 1990s: Poverty, Inequality and Poverty Dynamics'. Journal of the Asia Pacific Economy. 9(2): 145-169.

Liu, A. Y. C. (2001). 'Markets, Inequality and Poverty in Vietnam'. Asian Economic Journal. 15(2): 217-235.

Minot, N. (2000). 'Generating Disaggregated Poverty Maps: An Application to Vietnam'. World Development, 28(2): 319-331.

Minot, N., B. Baulch, and M. Epprecht (2003). 'Poverty and Inequality in Vietnam: Spatial Patterns and Geographic Determinants'. Research Report 48. Washington, DC: International Food Policy Research.

Niimi, Y., P. Vasudeva-Dutta, and L. A. Winters (2004). 'Storm in a Rice Bowl: Rice Reform and Poverty in Vietnam in the 1990s'. Journal of the Asia Pacific Economy, 9(2): 170-190. 
Ravallion, M. (2001). 'Growth, Inequality and Poverty: Looking Beyond Averages'. World Development, 29(11): 1803-1815.

Rodriguez, F., and D. Rodrik (2001). 'Trade Policy and Economic Growth: A Sceptic's Guide to the Cross-national Evidence', in B. S. Bernanke and K. Rogoff (eds), NBER Macroeconomics Annual 2000, vol. 15. Cambridge, MA: MIT Press.

Tarp, F., D. Roland-Holst, and J. Rand (2002). 'Trade and Income Growth in Vietnam: Estimates from a New Social Accounting Matrix’. Economic Systems Research, 14(2): 157-184.

Thanh, V. T. (2005). 'Vietnam's Trade Liberalization and International Economic Integration: Evolution, Problems, and Challenges'. ASEAN Economic Bulletin, 22(1): 75-91.

Winters, L. A. (2002). 'Trade Liberalisation and Poverty: What are the Links?' World Economy, 25(9): 1339-1367.

Winters, L. A., N. McCulloch, and A. McKay (2004). 'Trade Liberalization and Poverty: The Evidence so far'. Journal of Economic Literature, 42(1): 72-115.

World Bank (2001) Vietnam Living Standards Survey (VLSS), 1997-98. Basic Information. Washington, DC: World Bank, Poverty and Human Resources Division.

\section{APPENDIX}

There are three subsections in this Appendix. Section A1 provides the regression results for the wage equation $\operatorname{Eq}(5)$ and the adjustment coefficients for $\operatorname{Eq}(13)$. Section A2 provides the non-wage household income equation $\mathrm{Eq}(6)$ and the adjustment coefficient for $\mathrm{Eq}(14)$. Section A3 provides the regression results for the employment status equations $\mathrm{Eq}(7)-\mathrm{Eq}(8)$ and the adjustment coefficients for $\mathrm{Eq}(15)-\mathrm{Eq}(16)$. SDBR 
stands for shortest distance by road. In each table, we present the estimated coefficients and its associated standard errors on the top part of the table. In the middle part of the table, we present some diagnostic statistics for the regression. In the bottom part, we present the adjustment coefficients.

\section{A1 List of Acronyms}

[Table 4 about here]

\section{A2 Wage equation}

[Table 5 about here]

[Table 6 about here]

[Table 7 about here]

[Table 8 about here]

[Table 9 about here]

[Table 10 about here]

[Table 11 about here]

[Table 12 about here]

\section{A3 Non-wage income equation}

[Table 13 about here]

[Table 14 about here]

\section{A4 Employment status equations}

[Table 15 about here]

[Table 16 about here]

[Table 17 about here]

[Table 18 about here]

[Table 19 about here]

[Table 20 about here]

[Table 21 about here]

[Table 22 about here] 


\section{ACKNOWLEDGEMENTS}

The authors thank Alain de Janvry, Michael Epprecht, Peter Lanjouw and Elisabeth Sadoulet. An earlier version of this paper was presented at the UNU-WIDER Project Conference on the Impact of Globalization on the Poor in Asia. Fujii thanks the Government of Japan under the Millennium PHRD grant for financial support for the initial stage of this study. Usual caveats apply. 
TABLE 1 SUMMARY STATISTICS OF INCOME AND CONSUMPTION MEASURES

\begin{tabular}{|c|c|c|c|c|c|c|c|c|c|c|}
\hline $\begin{array}{l}\text { Column } \\
\text { Region }\end{array}$ & 1 Con. & $\begin{array}{l}2 \\
\text { (SE) }\end{array}$ & $\begin{array}{l}3 \\
P_{0}^{C}\end{array}$ & $\begin{array}{l}4 \\
\text { (SE) }\end{array}$ & $\begin{array}{l}5 \\
\text { Inc. }\end{array}$ & $\begin{array}{l}6 \\
\text { (SE) }\end{array}$ & $\begin{array}{l}7 \\
P_{0}^{I} \\
\end{array}$ & $\begin{array}{l}8 \\
(\mathrm{SE})\end{array}$ & $\begin{array}{l}9 \\
\text { Obs }\end{array}$ & $\begin{array}{l}10 \\
\text { Share }\end{array}$ \\
\hline Red River Delta & 2938 & (99) & 28.7 & (2.2) & 3094 & (188) & 36.9 & (2.3) & 1175 & 19.6 \\
\hline Northeast & 1987 & (94) & 55.8 & (4.9) & 1860 & (208) & 57.4 & $(4.2)$ & 731 & 15.0 \\
\hline Northwest & 1567 & (85) & 73.4 & $(4.9)$ & 1599 & (287) & 54.2 & (8.1) & 128 & 2.8 \\
\hline North & 2197 & (89) & 48.1 & $(4.2)$ & 2122 & (175) & 47.5 & (4.1) & 708 & 13.8 \\
\hline South Central Coast & 2648 & $(114)$ & 34.5 & $(4.3)$ & 3075 & (322) & 36.8 & $(4.7)$ & 628 & 8.5 \\
\hline Central Highlands & 1850 & $(241)$ & 57.9 & $(9.4)$ & 2191 & (622) & 52.4 & (8.2) & 276 & 2.8 \\
\hline Southeast & 4523 & (189) & 13.5 & (3.2) & 5860 & (395) & 15.2 & (3.0) & 1241 & 15.9 \\
\hline Mekong River Delta & 2536 & (87) & 36.9 & (2.4) & 3218 & (147) & 29.7 & (2.3) & 1112 & 21.5 \\
\hline Vietnam & 2764 & (43) & 37.4 & (1.3) & 3171 & (85) & 37.4 & (1.4) & 5999 & 100.0 \\
\hline
\end{tabular}

Note: All the standard errors are calculated by bootstrapping accounting for the strata, clustering and weights. Poverty rates, their associated standard errors and population share are expressed in percentage.

TABLE 2 CHANGES IN AGGREGATE INDICES FROM THE MACROECONOMIC CGE UNDER VARIOUS SCENARIOS

\begin{tabular}{lccc}
\hline (Scenario) & UL & FL & DSDT \\
\hline Real GDP & 3.97 & 5.31 & -0.27 \\
GDP at factor cost & 3.69 & 12.90 & -1.23 \\
GDP at market prices & -2.81 & 5.81 & -1.25 \\
Real consumption & 7.02 & 10.71 & -0.47 \\
Imports & 16.46 & 27.54 & -1.28 \\
Exports & 14.02 & 20.53 & -0.82 \\
Consumer price index & -5.62 & -1.33 & -0.61 \\
Terms of trade & -2.89 & 2.18 & -0.74 \\
\hline
\end{tabular}

Note: The numbers are expressed in percentage. 
TABLE 3 BASELINE SECTORAL OUTPUT IN TERMS OF MILLION US DOLLARS FOR THE YEAR 2000, AND CHANGES IN SECTORAL OUTPUT AND PRICES IN PERCENTAGE

\begin{tabular}{|c|c|c|c|c|c|c|c|}
\hline \multirow{2}{*}{$\begin{array}{l}\text { Sector } \\
\text { (Scenario) }\end{array}$} & \multirow{2}{*}{$\begin{array}{l}\text { Baseline } \\
\text { output }\end{array}$} & \multicolumn{3}{|c|}{ Change in output } & \multicolumn{3}{|c|}{ Change in price } \\
\hline & & $U L$ & $F L$ & $D S D T$ & $U L$ & $F L$ & $D S D T$ \\
\hline Rice & 105145 & 1.11 & 4.50 & 0.05 & -0.80 & 8.54 & -0.76 \\
\hline Raw rubber & 2442 & -1.44 & 9.42 & 0.37 & 0.19 & 15.23 & -0.54 \\
\hline Coffee bean & 7262 & 1.96 & -5.02 & -0.64 & -0.55 & 1.32 & -1.18 \\
\hline Sugar cane & 2911 & 0.45 & 6.86 & -0.69 & -1.74 & 12.96 & -1.61 \\
\hline Other crops & 35761 & 0.43 & -0.58 & -0.18 & -0.09 & 5.54 & -1.09 \\
\hline Pig & 13687 & 3.55 & 5.75 & -0.33 & -1.08 & 5.19 & -0.94 \\
\hline Cattle & 1107 & 4.18 & 6.80 & -0.25 & -1.11 & 5.19 & -0.88 \\
\hline Poultry & 6116 & 1.01 & 1.57 & -0.10 & 0.70 & 8.10 & -1.07 \\
\hline Other livestocks & 5242 & 4.84 & 10.43 & -0.09 & -2.11 & 3.72 & -0.81 \\
\hline Irrigation services & 1277 & 1.35 & 3.24 & -0.13 & -1.61 & 3.72 & -0.78 \\
\hline Other agr. srvices & 4839 & 1.24 & 4.00 & -0.04 & -2.23 & 2.73 & -0.71 \\
\hline Forestry & 7717 & 1.68 & 0.11 & 0.20 & -0.07 & 5.34 & -0.83 \\
\hline Fish & 26000 & 6.57 & 2.94 & -1.77 & -2.81 & 1.59 & -0.82 \\
\hline Energy & 57461 & -3.29 & -7.80 & 0.91 & -3.27 & 0.21 & -0.57 \\
\hline Mining & 3529 & 0.25 & -4.72 & 0.54 & -1.20 & 3.22 & -0.66 \\
\hline Meat & 2883 & 1.45 & -1.09 & 0.26 & -1.45 & 5.31 & -1.11 \\
\hline Dairy products & 4815 & -1.59 & 24.47 & 3.78 & -5.76 & -4.10 & -1.01 \\
\hline Fruits and vegetables & 1739 & -2.46 & -0.77 & -0.28 & -1.65 & 3.34 & -0.83 \\
\hline Rafined sugar & 6794 & 0.26 & 7.93 & -0.80 & -0.90 & 8.30 & -1.09 \\
\hline Coffee and tea bevereages & 1538 & 1.80 & 1.79 & -0.95 & -1.15 & 3.39 & -0.90 \\
\hline Other bev. and tobacco & 21428 & -12.24 & -12.32 & -0.38 & -4.11 & 0.83 & -0.79 \\
\hline Sea food & 20412 & 6.79 & -6.94 & -3.11 & -4.96 & -0.61 & -0.68 \\
\hline Animal feed & 4219 & -9.29 & -11.39 & 0.10 & -2.89 & 2.31 & -0.76 \\
\hline Other processed foods & 19521 & -4.80 & -6.18 & -0.56 & -3.10 & 1.88 & -0.72 \\
\hline Building materials & 36658 & 2.27 & 1.72 & -0.04 & -1.77 & 3.08 & -0.74 \\
\hline Industrial chemicals & 24785 & 0.23 & 10.42 & 0.48 & -2.84 & -1.06 & -0.46 \\
\hline Agro chemicals & 5909 & -5.35 & -10.80 & 1.08 & -2.55 & 0.36 & -0.47 \\
\hline Tech manufacturing & 6184 & 29.04 & 14.74 & 4.52 & -8.19 & -5.59 & -0.65 \\
\hline Vehicles & 29836 & -32.79 & -32.02 & 0.37 & -15.52 & -13.69 & -0.43 \\
\hline Machinery & 14014 & 8.71 & 9.91 & 1.60 & -6.74 & -5.32 & -0.39 \\
\hline Metals & 18976 & 3.41 & 1.20 & 0.66 & -5.10 & -3.09 & -0.31 \\
\hline Textile and apparel & 58078 & 38.19 & 67.32 & -4.25 & -17.09 & -16.17 & 0.01 \\
\hline Other industry & 20574 & -2.29 & -5.76 & 0.82 & -8.61 & -6.13 & -0.42 \\
\hline Utilities & 19061 & 2.46 & 3.21 & -0.14 & -0.26 & 5.63 & -0.84 \\
\hline Construction & 84600 & 4.62 & 10.31 & -0.83 & -3.08 & 0.64 & -0.56 \\
\hline Trade and transport & 94185 & 6.75 & 10.02 & -0.53 & -3.38 & 1.80 & -0.77 \\
\hline Private service & 101236 & 3.16 & 2.52 & -0.21 & -0.97 & 4.03 & -0.70 \\
\hline Public service & 56309 & 1.63 & 0.27 & 0.18 & -2.54 & 2.13 & -0.68 \\
\hline
\end{tabular}


TABLE 4 LIST OF ACRONYMS

ASEAN

CGE

DSDT

FL

GDP

GSO

SAE

SAM

SDBR

UL

VLSS

WTO
Association of Southeast Asian Nations

Computable General Equilibrium

Doha Special and Differential Treatment

Full Liberalization

Gross Domestic Product

General Statistical Office

Small Area Estimation

Social Accounting Matrix

Shortest Distance By Road

Unilateral Liberalization

Vietnam Living Standandard Survey

World Trade Organization 
TABLE 5 WAGE EQUATION FOR RURAL/MALE/UNSKILLED

\begin{tabular}{|c|c|c|}
\hline Description & Est. & SE \\
\hline Arable land in district (thousand $\mathrm{km}^{2}$ ) & $0.018^{* \star *}$ & $(0.005)$ \\
\hline Head is married & $0.902^{*}$ & $(0.472)$ \\
\hline Max. education, at least secondary completed & $-2.801^{* * *}$ & $(0.981)$ \\
\hline Average annual humidity duration & $-0.024^{\star * *}$ & $(0.005)$ \\
\hline Head's child & $-0.962^{* * *}$ & $(0.272)$ \\
\hline Not immediately related to head & $-1.227^{* * *}$ & $(0.321)$ \\
\hline Age squared/1000 & $-0.554^{\star \star \star}$ & $(0.141)$ \\
\hline Female head & $-0.366^{* *}$ & $(0.147)$ \\
\hline Head has at least secondary education & $3.820^{* * *}$ & $(1.093)$ \\
\hline Total length of road in district & $-1.870^{\star \star *}$ & $(0.364)$ \\
\hline Number of elderly people in $\mathrm{HH}$ & $-1.381^{* * *}$ & $(0.329)$ \\
\hline Maximum monthly precipitation in a year & $2.294^{\star * *}$ & $(0.594)$ \\
\hline Age of head & $0.036^{\star \star \star}$ & $(0.008)$ \\
\hline Ratio of elderly in $\mathrm{HH}$ & $3.825^{\star \star *}$ & $(1.347)$ \\
\hline Spouse has at least 8 years of schooling & $0.729^{\star \star *}$ & $(0.230)$ \\
\hline An Giang province & $-0.363^{*}$ & $(0.213)$ \\
\hline Bac Lieu province & $0.998^{\star *}$ & $(0.390)$ \\
\hline Can Tho province & $-0.847^{\star * *}$ & $(0.280)$ \\
\hline Constant & $29.972^{\star \star \star}$ & $(4.794)$ \\
\hline Obs & 255 & \\
\hline$F(18,236)$ & 6.14 & \\
\hline P-Value & 0.000 & \\
\hline$R^{2}$ & 0.319 & \\
\hline$\sigma_{\mu}$ & 0.839 & \\
\hline$\Delta \alpha_{U L}$ & -0.002 & \\
\hline$\Delta \alpha_{F L}$ & 0.082 & \\
\hline$\Delta \alpha_{D S D T}$ & -0.010 & \\
\hline
\end{tabular}

Note: *significant at a $10 \%$ level.

**significant at a $5 \%$ level.

***significant at a $1 \%$ level. 
TABLE 6 WAGE EQUATION FOR RURAL/MALE/SKILLED

\begin{tabular}{|c|c|c|}
\hline Description & Est. & SE \\
\hline Head's ethnicity is Kinh & $0.397^{\star \star *}$ & $(0.109)$ \\
\hline Max. education, at least college & $0.339^{\star \star}$ & $(0.140)$ \\
\hline Spouse & $0.354^{\star \star \star}$ & $(0.136)$ \\
\hline Distance from district town to a city+ & $0.001^{* \star *}$ & $(0.000)$ \\
\hline Age & -0.001 & $(0.003)$ \\
\hline Number of Dependents & $0.065^{\star *}$ & $(0.027)$ \\
\hline Ratio of children in $\mathrm{HH}$ & $-0.551^{* * *}$ & $(0.183)$ \\
\hline Dong Nai province & $0.373^{\star \star}$ & $(0.156)$ \\
\hline Tien Giang province & $-0.444^{\star * *}$ & $(0.138)$ \\
\hline Quang Tri province & $-1.405^{\star * *}$ & $(0.282)$ \\
\hline Nghe An province & $-0.714^{\star * *}$ & $(0.139)$ \\
\hline Thua Thien-Hue province & $-1.004^{* * *}$ & $(0.219)$ \\
\hline Ho Chi Minh City & $0.845^{\star \star \star}$ & $(0.165)$ \\
\hline Binh Duong province & $0.885^{\star \star}$ & $(0.429)$ \\
\hline Ha Noi province & $0.503^{* *}$ & $(0.220)$ \\
\hline Bac Giang province & $-0.720^{* *}$ & $(0.283)$ \\
\hline Nam Dinh province & $-0.474^{\star \star}$ & $(0.182)$ \\
\hline Hai Duong province & $-0.796^{* \star *}$ & $(0.146)$ \\
\hline Can Tho province & $-0.899^{* * *}$ & $(0.291)$ \\
\hline Constant & $7.580^{* * *}$ & $(0.150)$ \\
\hline Obs & 750 & \\
\hline$F(19,730)$ & 12.06 & \\
\hline P-Value & 0.000 & \\
\hline$R^{2}$ & 0.239 & \\
\hline$\sigma_{\mu}$ & 0.790 & \\
\hline$\Delta \alpha_{U L}$ & -0.027 & \\
\hline$\Delta \alpha_{F L}$ & 0.030 & \\
\hline$\Delta \alpha_{D S D T}$ & -0.008 & \\
\hline
\end{tabular}

Note: *significant at a $10 \%$ level.

**significant at a $5 \%$ level.

***significant at a $1 \%$ level.

+city with population greater than $1,000,000$. 
TABLE 7 WAGE EQUATION FOR RURAL/FEMALE/UNSKILLED

\begin{tabular}{|c|c|c|}
\hline Description & Est. & SE \\
\hline Distance from district town to a city+ & 0.029 & $(0.017)$ \\
\hline Length of navigable river in district $(\mathrm{km})$ & $-0.020^{\star \star \star}$ & $(0.005)$ \\
\hline Max. education, at least 8 years & $-0.879^{* * *}$ & $(0.220)$ \\
\hline Arable land in district $\left(\mathrm{km}^{2}\right)$ & 0.000 & $(0.001)$ \\
\hline Parent of the head & $-1.515^{\star}$ & $(0.868)$ \\
\hline HH owns house & $1.162^{*}$ & $(0.668)$ \\
\hline Distance from district town to a city++ & $-0.007^{\star \star \star}$ & $(0.005)$ \\
\hline Percentage of area covered by plant/forest in district & $-0.112^{\star \star \star}$ & $(0.030)$ \\
\hline Distance from district town to a city+++ & 0.005 & $(0.001)$ \\
\hline Ratio of dependents in $\mathrm{HH}$ & $3.387^{\star \star \star}$ & $(0.926)$ \\
\hline House is at least 10 years old & $1.278^{\star * *}$ & $(0.380)$ \\
\hline Head's religion is Catholic & $-0.584^{*}$ & $(0.332)$ \\
\hline Length of main road (km) & $5.740^{*}$ & $(2.870)$ \\
\hline Head has at least 5 years of education & $0.328^{*}$ & $(0.188)$ \\
\hline Average elevation of district $(\mathrm{km})$ & $-1.328^{*}$ & $(0.726)$ \\
\hline Water is not from running water/rain/well & $0.441^{\star *}$ & $(0.173)$ \\
\hline $\mathrm{HH}$ size & $0.235^{\star \star \star}$ & $(0.069)$ \\
\hline Number of dependents & $-0.655^{* \star *}$ & $(0.179)$ \\
\hline Semi-permanent house & $1.062^{\star \star \star}$ & $(0.375)$ \\
\hline Thua Thien-Hue province & $2.085^{\star \star \star}$ & $(0.741)$ \\
\hline Ho Chi Minh City & $1.259^{\star *}$ & $(0.539)$ \\
\hline Constant & $3.748^{\star \star *}$ & $(0.879)$ \\
\hline Obs & 169 & \\
\hline$F(21,147)$ & 3.82 & \\
\hline P-Value & 0.000 & \\
\hline$R^{2}$ & 0.353 & \\
\hline$\sigma_{\mu}$ & 0.884 & \\
\hline$\Delta \alpha_{U L}$ & -0.013 & \\
\hline$\Delta \alpha_{F L}$ & 0.061 & \\
\hline$\triangle \alpha_{D S D T}$ & -0.008 & \\
\hline
\end{tabular}

Note: *significant at a $10 \%$ level.

**significant at a $5 \%$ level.

$* * *$ significant at a $1 \%$ level.

+city with population greater than 10,000

++ city with a population greater than 100,000

++ city with a population greater than 250,000 . 
TABLE 8 WAGE EQUATION FOR RURAL/FEMALE/SKILLED

\begin{tabular}{|c|c|c|}
\hline Description & Est. & SE \\
\hline Head at least some education & $0.376^{* *}$ & $(0.173)$ \\
\hline At least secondary completed & $0.411^{* * *}$ & $(0.090)$ \\
\hline Head's child & $0.235^{\star *}$ & $(0.108)$ \\
\hline Water from well & $0.324^{* * *}$ & $(0.092)$ \\
\hline Age & $0.012^{* *}$ & $(0.005)$ \\
\hline Minimum monthly precipitation in a year & $-0.014^{* * *}$ & $(0.004)$ \\
\hline $\mathrm{HH}$ has radio & $0.292^{* \star *}$ & $(0.078)$ \\
\hline Tien Giang province & $-0.802^{\star * *}$ & $(0.232)$ \\
\hline Quang Tri province & $-2.115^{\star \star *}$ & $(0.420)$ \\
\hline Kien Giang province & $-0.911^{* * *}$ & $(0.329)$ \\
\hline Hai Duong province & $-1.587^{\star \star \star}$ & $(0.238)$ \\
\hline Quang Binh province & $-1.146^{\star *}$ & $(0.503)$ \\
\hline Ho Chi Minh City & $0.497^{\star * \star}$ & $(0.188)$ \\
\hline Ha Tay province & $-0.593^{* \star \star}$ & $(0.218)$ \\
\hline Constant & $6.880^{\star * *}$ & $(0.262)$ \\
\hline Obs & 405 & \\
\hline$F(14,390)$ & 17.26 & \\
\hline P-Value & 0.000 & \\
\hline$R^{2}$ & 0.383 & \\
\hline$\sigma_{\mu}$ & 0.770 & \\
\hline$\Delta \alpha_{U L}$ & -0.013 & \\
\hline$\Delta \alpha_{F L}$ & 0.032 & \\
\hline$\Delta \alpha_{D S D T}$ & -0.006 & \\
\hline
\end{tabular}

Note: *significant at a $10 \%$ level.

**significant at a $5 \%$ level.

$* * *$ significant at a $1 \%$ level. 
TABLE 9 WAGE EQUATION FOR URBAN/MALE/UNSKILLED

\begin{tabular}{|c|c|c|}
\hline Description & Est. & SE \\
\hline Head is married & $-1.421^{\star * *}$ & $(0.531)$ \\
\hline North central coast region & $-1.171^{\star *}$ & $(0.525)$ \\
\hline Water from well & $-0.459^{\star \star \star}$ & $(0.170)$ \\
\hline Age of head & $-0.018^{* * *}$ & $(0.006)$ \\
\hline House is shared with other $\mathrm{HH}(\mathrm{s})$ & $0.580^{\star \star}$ & $(0.245)$ \\
\hline Water from rain & $-1.735^{\star * \star}$ & $(0.417)$ \\
\hline Constant & $9.602^{* * *}$ & $(0.337)$ \\
\hline Obs & 84 & \\
\hline$F(6,77)$ & 9.23 & \\
\hline P-Value & 0.000 & \\
\hline$R^{2}$ & 0.418 & \\
\hline$\sigma_{\mu}$ & 0.679 & \\
\hline$\Delta \alpha_{U L}$ & 0.023 & \\
\hline$\Delta \alpha_{F L}$ & 0.100 & \\
\hline$\Delta \alpha_{D S D T}$ & -0.002 & \\
\hline
\end{tabular}

Note: *significant at a $10 \%$ level.

**significant at a $5 \%$ level.

***significant at a $1 \%$ level. 
TABLE 10 WAGE EQUATION FOR URBAN/MALE/SKILLED

\begin{tabular}{|c|c|c|}
\hline Description & Est. & SE \\
\hline Logarithmic population of district & $0.162^{\star * *}$ & $(0.033)$ \\
\hline Never married & $-0.356^{\star \star \star}$ & $(0.062)$ \\
\hline Logarithmic living area & $0.411^{* \star *}$ & $(0.062)$ \\
\hline Temporary house & $1.522^{\star * \star}$ & $(0.262)$ \\
\hline Length of navigable river in district $(\mathrm{km})$ & $-0.024^{\star * *}$ & $(0.004)$ \\
\hline Percentage of bare rock surface in district & $-0.027^{* *}$ & $(0.007)$ \\
\hline $\mathrm{HH}$ size & $-0.049^{* \star}$ & $(0.014)$ \\
\hline Head's religion is Catholic & $-0.279^{\star * *}$ & $(0.127)$ \\
\hline Binh Thuan province & $-0.488^{* *}$ & $(0.246)$ \\
\hline Thua Thien-Hue province & $-0.699^{* * *}$ & $(0.222)$ \\
\hline Ha Noi province & $-0.195^{\star *}$ & $(0.090)$ \\
\hline Hai Phong province & $-0.353^{* * *}$ & $(0.135)$ \\
\hline Nam Dinh province & $-0.740^{\star \star \star}$ & $(0.209)$ \\
\hline Dong Thap province & $-0.484^{\star \star \star}$ & $(0.152)$ \\
\hline Yen Bai province & $-0.505^{* * *}$ & $(0.188)$ \\
\hline Son La province & -1.171 & $(0.955)$ \\
\hline Constant & $6.073^{* * *}$ & $(0.452)$ \\
\hline Obs & 819 & \\
\hline$F(16,802)$ & 17.90 & \\
\hline P-Value & 0.000 & \\
\hline$R^{2}$ & 0.263 & \\
\hline$\sigma_{\mu}$ & 0.814 & \\
\hline$\Delta \alpha_{U L}$ & 0.021 & \\
\hline$\Delta \alpha_{F L}$ & 0.097 & \\
\hline$\triangle \alpha_{D S D T}$ & -0.010 & \\
\hline
\end{tabular}

Note: *significant at a $10 \%$ level.

**significant at a $5 \%$ level.

$* * *$ significant at a $1 \%$ level. 
TABLE 11 WAGE EQUATION FOR URBAN/FEMALE/UNSKILLED

\begin{tabular}{|c|c|c|}
\hline Description & Est. & SE \\
\hline Number of dependents & $-0.744^{\star * *}$ & $(0.229)$ \\
\hline Head has at least 8 years of education & $-0.828^{\star * *}$ & $(0.267)$ \\
\hline Head's religion is Catholic & $-0.919^{* *}$ & $(0.343)$ \\
\hline $\mathrm{HH}$ size & $0.312^{* * *}$ & $(0.092)$ \\
\hline Head is married & $2.093^{* * *}$ & $(0.668)$ \\
\hline Age & 0.008 & $(0.008)$ \\
\hline Head's ethnicity is Kinh & $-0.541^{\star *}$ & $(0.253)$ \\
\hline Ratio of dependents in $\mathrm{HH}$ & $4.621^{* * *}$ & $(1.258)$ \\
\hline House is $3-9$ years old & $0.865^{\star * *}$ & $(0.251)$ \\
\hline Constant & $6.503^{* * *}$ & $(0.653)$ \\
\hline Obs & 67 & \\
\hline$F(9,57)$ & 4.47 & \\
\hline P-Value & 0.000 & \\
\hline$R^{2}$ & 0.414 & \\
\hline$\sigma_{\mu}$ & 0.791 & \\
\hline$\Delta \alpha_{U L}$ & -0.016 & \\
\hline$\Delta \alpha_{F L}$ & 0.095 & \\
\hline$\Delta \alpha_{D S D T}$ & -0.010 & \\
\hline
\end{tabular}

Note: *significant at a $10 \%$ level.

**significant at a $5 \%$ level.

$* * *$ significant at a $1 \%$ level. 
TABLE 12 WAGE EQUATION FOR URBAN/FEMALE/SKILLED

\begin{tabular}{lcc}
\hline Description & Est. & SE \\
\hline Maximum education, at least 10 years & $0.300^{* * *}$ & $(0.081)$ \\
Distance from district town to a city+ & $-0.002^{* * *}$ & $(0.000)$ \\
House is at least 10 years old & $-0.210^{* * *}$ & $(0.066)$ \\
Head has no religion & $0.229^{* * *}$ & $(0.078)$ \\
Average annual humidity duration & $-0.010^{* * *}$ & $(0.002)$ \\
At least 8 years of education & $0.327^{* * *}$ & $(0.091)$ \\
Distance to provincial town & $-0.012^{* * *}$ & $(0.004)$ \\
Age & $0.010^{* * *}$ & $(0.003)$ \\
Hai Phong province & $-0.531^{* * *}$ & $(0.157)$ \\
Nam Dinh province & $-0.931^{* * *}$ & $(0.256)$ \\
Tien Giang province & $-0.487^{* * *}$ & $(0.180)$ \\
Constant & $18.180 * * *$ & $(1.988)$ \\
Obs & 618 & \\
$\mathrm{~F}(11,606)$ & 21.22 & \\
P-Value & 0.000 & \\
$R^{2}$ & 0.278 & \\
$\sigma_{\mu} \alpha_{U L}$ & 0.766 & \\
$\triangle \alpha_{F L}$ & 0.012 & \\
\hline
\end{tabular}

Note: *significant at a $10 \%$ level.

**significant at a $5 \%$ level.

$* * *$ significant at a $1 \%$ level.

+ city with population greater than 250,000 . 
TABLE 13 NON-WAGE EQUATION FOR RURAL AREAS

\begin{tabular}{|c|c|c|}
\hline Description & Est. & SE \\
\hline Number of self-employed & $0.507^{* * *}$ & $(0.037)$ \\
\hline Number of self-employed squared & $-0.053^{\star \star \star}$ & $(0.006)$ \\
\hline $\mathrm{HH}$ has TV & $0.409^{\star * \star}$ & $(0.037)$ \\
\hline Head's ethnicity is Kinh & $0.360^{\star * *}$ & $(0.060)$ \\
\hline Ratio of students in $\mathrm{HH}$ & $0.659^{\star * \star}$ & $(0.085)$ \\
\hline Max. educ., at least 10 yrs & $0.231^{\star * *}$ & $(0.039)$ \\
\hline Max. educ., at least some education & $0.296^{\star \star \star}$ & $(0.098)$ \\
\hline $\mathrm{HH}$ has a radio & $0.119^{* * *}$ & $(0.034)$ \\
\hline House is $3-9$ years old & $-0.670^{\star * *}$ & $(0.098)$ \\
\hline Non-flushing toilet & $-0.463^{* * *}$ & $(0.092)$ \\
\hline Electricity available & $0.317^{* * *}$ & $(0.049)$ \\
\hline Ratio of elderly in $\mathrm{HH}$ & $0.500 * * *$ & $(0.101)$ \\
\hline Max. educ., at least 5 yrs & $0.218^{* \star \star}$ & $(0.053)$ \\
\hline Semi-permanent house & $-0.361^{* * *}$ & $(0.056)$ \\
\hline Log of the living area & $0.143^{* * *}$ & $(0.017)$ \\
\hline Head's marital status is divorced/separated/widowed & $-0.200^{\star * *}$ & $(0.049)$ \\
\hline Head's age & $0.003^{* \star}$ & $(0.002)$ \\
\hline Arable land in district (thousand $\mathrm{km}^{2}$ ) & $0.014^{* \star *}$ & $(0.002)$ \\
\hline Thua Thien-Hue province & $1.552^{\star \star \star}$ & $(0.166)$ \\
\hline Monthly minimum precipitation in a year & $-0.030^{\star \star \star}$ & $(0.003)$ \\
\hline Bac Ninh province & $0.426^{\star * *}$ & $(0.100)$ \\
\hline Bac Giang province & $-0.404^{\star \star \star}$ & $(0.109)$ \\
\hline Ha Tinh province & $1.169^{* * *}$ & $(0.222)$ \\
\hline Hai Duong province & $-0.477^{\star * \star}$ & $(0.089)$ \\
\hline Quang Tri province & $0.835^{\star * *}$ & $(0.188)$ \\
\hline Vinh Phuc province & $-0.683^{\star * \star}$ & $(0.173)$ \\
\hline Phu Tho province & $-0.436^{\star \star \star}$ & $(0.101)$ \\
\hline Lam Dong province & $0.750^{\star * *}$ & $(0.181)$ \\
\hline Elevation of district town & $-0.425^{\star \star \star}$ & $(0.124)$ \\
\hline Qhuang Ninh province & $0.552 * * *$ & $(0.165)$ \\
\hline Long An province & $-0.527^{* * *}$ & $(0.133)$ \\
\hline Thai Binh province & $-0.372^{\star \star *}$ & $(0.105)$ \\
\hline Percentage of area covered by plant or forest in district & $-0.023^{\star \star \star}$ & $(0.008)$ \\
\hline Tra Vinh province & $-0.430^{* * *}$ & $(0.131)$ \\
\hline Total length of road in district $(1000 \mathrm{~km})$ & $-0.346^{\star \star *}$ & $(0.103)$ \\
\hline Tien Giang province & $-0.282^{* * *}$ & $(0.109)$ \\
\hline Dong Thap province & $-0.403^{* * *}$ & $(0.126)$ \\
\hline Thai Nguyen province & $-0.457^{\star * *}$ & $(0.173)$ \\
\hline Ha Nam province & $-0.283^{\star \star *}$ & $(0.105)$ \\
\hline Tuyen Quang province & $0.536^{\star * *}$ & $(0.187)$ \\
\hline Binh Duong Province & $-0.400^{\star \star}$ & $(0.168)$ \\
\hline Proportion of steep slope (8-15\%) & $0.012^{\star \star *}$ & $(0.003)$ \\
\hline Ninh Thuan province & $-0.721^{\star \star \star}$ & $(0.204)$ \\
\hline Yen Bai province & $-0.368^{* *}$ & $(0.171)$ \\
\hline Quang Nam province & $-0.236^{\star}$ & $(0.130)$ \\
\hline Hoa Binh province & $-0.283^{\star \star}$ & $(0.134)$ \\
\hline
\end{tabular}




\section{Constant}

Obs

$\mathrm{F}(46,4201)$

$\mathrm{P}$-Value

$R^{2}$

$\sigma_{\gamma}$

$\Delta \gamma_{U L}$

$\Delta \gamma_{F L}$

$\Delta \gamma_{D S D T}$

Note: *significant at a $10 \%$ level.

**significant at a 5\% level.

***significant at a $1 \%$ level.

+ city with population greater than 250,000 . $6.813^{\star \star *}$

4248

56.58

0.000

0.383

1.032

0.013

0.100

$-0.012$ 
TABLE 14 NON-WAGE EQUATION FOR URBAN AREAS

\begin{tabular}{|c|c|c|}
\hline Description & Est. & SE \\
\hline Number of self-employed & $0.903^{* * *}$ & $(0.063)$ \\
\hline Number of self-employed squared & $-0.106^{* * *}$ & $(0.016)$ \\
\hline $\mathrm{HH}$ has TV & $0.394^{\star * *}$ & $(0.082)$ \\
\hline Non-flushing toilet & $-0.194^{\star *}$ & $(0.076)$ \\
\hline Max. educ., at least 10 years & $0.332^{* * *}$ & $(0.066)$ \\
\hline Ratio of dependants in $\mathrm{HH}$ & $0.768^{* * *}$ & $(0.129)$ \\
\hline Logarithmic living area & $0.346^{\star * \star}$ & $(0.066)$ \\
\hline Semi-permanent house & $-0.347^{\star \star *}$ & $(0.072)$ \\
\hline House is $3-9$ years old & $0.754^{\star \star \star}$ & $(0.278)$ \\
\hline House is shared with other $\mathrm{HH}(\mathrm{s})$ & $-0.427^{\star * *}$ & $(0.109)$ \\
\hline Logarithmic population in district & $0.214^{* * *}$ & $(0.029)$ \\
\hline Minimum monthly precipitation in a year & $-0.034^{* * *}$ & $(0.005)$ \\
\hline Proportion of very deep slope $(30 \%+)$ & $0.033^{* * *}$ & $(0.008)$ \\
\hline Hai Phong province & $0.743^{\star * *}$ & $(0.144)$ \\
\hline Maximum monthly precipitation in a year & $1.425^{\star \star \star}$ & $(0.491)$ \\
\hline Bac Ninh province & $0.716^{\star * \star}$ & $(0.234)$ \\
\hline Dong Nai province & $-0.333^{* *}$ & $(0.168)$ \\
\hline Max. educ., at least college & $0.195^{\star \star}$ & $(0.090)$ \\
\hline Constant & $3.915^{\star \star \star}$ & $(0.458)$ \\
\hline Obs & 1676 & \\
\hline$F(18,1657)$ & 49.82 & \\
\hline P-Value & 0.000 & \\
\hline$R^{2}$ & 0.351 & \\
\hline$\sigma_{\gamma}$ & 1.193 & \\
\hline$\Delta \gamma_{U L}$ & 0.013 & \\
\hline$\Delta \gamma_{F L}$ & 0.100 & \\
\hline$\Delta \gamma_{D S D T}$ & -0.013 & \\
\hline
\end{tabular}

Note: *significant at a $10 \%$ level.

$* *$ significant at a $5 \%$ level.

$* * *$ significant at a $1 \%$ level. 
TABLE 15 EMPLOYMENT STATUS EQUATIONS FOR RURAL/MALE/UNSKILLED

\begin{tabular}{|c|c|c|c|c|}
\hline \multirow[t]{2}{*}{ Description } & \multicolumn{2}{|c|}{ Wage-earner } & \multicolumn{2}{|c|}{ Self-employed } \\
\hline & Est. & SE & Est. & SE \\
\hline Spouse & $-1.772^{* \star *}$ & $(0.517)$ & -0.513 & $(0.580)$ \\
\hline Head's child & -0.491 & $(0.369)$ & -0.548 & $(0.391)$ \\
\hline Literate & $1.070^{\star \star *}$ & $(0.234)$ & $0.710^{\star * *}$ & $(0.262)$ \\
\hline Head's religion is Catholic & -0.653 & $(0.458)$ & -0.830 & $(0.534)$ \\
\hline Head has no religion & -0.390 & $(0.253)$ & $-0.560^{* \star}$ & $(0.283)$ \\
\hline Semi-permanent house & $0.840^{* * *}$ & $(0.283)$ & 0.511 & $(0.324)$ \\
\hline House is $6+$ years old & -0.210 & $(0.322)$ & $-1.226^{\star \star \star}$ & $(0.401)$ \\
\hline House is $3-9$ years old & $2.358^{\star \star *}$ & $(0.735)$ & $1.564^{*}$ & $(0.833)$ \\
\hline Water from well & $1.553^{\star * *}$ & $(0.575)$ & $1.626^{\star \star *}$ & $(0.617)$ \\
\hline Water not from running water/rain water/well & $1.613^{\star \star \star}$ & $(0.568)$ & $1.509^{* *}$ & $(0.607)$ \\
\hline Quang Ngai province & $1.759^{\star}$ & $(0.937)$ & 0.824 & $(1.146)$ \\
\hline Dac Lac province & -2.325 & $(1.538)$ & -2.110 & $(1.797)$ \\
\hline Lam Dong province & $-4.036^{\star * *}$ & $(1.268)$ & -2.248 & $(1.438)$ \\
\hline Tay Ninh province & 1.064 & $(0.659)$ & $1.292^{*}$ & $(0.758)$ \\
\hline Long An province & 0.696 & $(0.848)$ & $1.660^{*}$ & $(0.915)$ \\
\hline An Giang province & $1.032^{*}$ & $(0.591)$ & $1.930^{\star \star \star}$ & $(0.624)$ \\
\hline Tien Giang province & -0.362 & $(0.426)$ & $1.137^{\star *}$ & $(0.480)$ \\
\hline Ben Tre province & $1.416^{\star \star}$ & $(0.672)$ & 0.446 & $(0.830)$ \\
\hline Kien Giang province & 0.643 & $(0.549)$ & 0.954 & $(0.599)$ \\
\hline Tra Vinh province & $1.888^{*}$ & $(1.017)$ & 1.342 & $(1.084)$ \\
\hline Soc Trang province & 0.659 & $(0.502)$ & $1.861^{\star \star \star}$ & $(0.537)$ \\
\hline Bac Lieu province & 1.314 & $(0.809)$ & $2.270^{\star *}$ & $(0.879)$ \\
\hline Age & $0.147^{\star * *}$ & $(0.051)$ & $0.179^{\star \star \star}$ & $(0.059)$ \\
\hline Age of spouse & $0.011^{\star *}$ & $(0.005)$ & 0.007 & $(0.006)$ \\
\hline Ratio of dependents in $\mathrm{HH}$ & $-1.330^{* *}$ & $(0.649)$ & $-1.841^{* *}$ & $(0.745)$ \\
\hline Ratio of students in $\mathrm{HH}$ & $3.539^{* * *}$ & $(0.807)$ & $2.972^{* \star *}$ & $(0.905)$ \\
\hline Age squared/1000 & $-2.356^{* * *}$ & $(0.608)$ & $-3.412^{* * *}$ & $(0.753)$ \\
\hline Distance from district town to a city+ & -0.023 & $(0.007)$ & $-0.026^{\star \star *}$ & $(0.008)$ \\
\hline Average elevation of district & $0.006^{\star \star \star}$ & $(0.001)$ & $0.004^{\star \star \star}$ & $(0.001)$ \\
\hline Length of navigable river in district $(\mathrm{km})$ & $-0.012^{*}$ & $(0.006)$ & $-0.024^{\star * *}$ & $(0.008)$ \\
\hline Total area over $1500 \mathrm{~m}$ in elevation in district & $-0.289^{* * *}$ & $(0.082)$ & $-0.267^{\star *}$ & $(0.114)$ \\
\hline Constant & $-2.230^{*}$ & $(1.220)$ & -1.831 & $(1.331)$ \\
\hline Obs & 1382 & & & \\
\hline$\chi_{66}^{2}$ & 400.55 & & & \\
\hline$\Delta a_{U L}$ & 0.011 & & 0.040 & \\
\hline$\Delta a_{F L}$ & 0.432 & & 0.430 & \\
\hline$\triangle a_{D S D T}$ & -0.058 & & -0.058 & \\
\hline
\end{tabular}

Note: *significant at a $10 \%$ level.

**significant at a $5 \%$ level.

***significant at a $1 \%$ level.

+ city with population greater than 50,000 . 
TABLE 16 EMPLOYMENT STATUS EQUATIONS FOR RURAL/MALE/SKILLED

\begin{tabular}{|c|c|c|c|c|}
\hline \multirow[t]{2}{*}{ Description } & \multicolumn{2}{|c|}{ Wage-earner } & \multicolumn{2}{|c|}{ Self-employed } \\
\hline & Est. & SE & Est. & SE \\
\hline Age of spouse squared/1000 & $0.567^{\star \star}$ & $(0.241)$ & $0.712^{* * *}$ & $(0.264)$ \\
\hline Spouse & $-1.026^{* * *}$ & $(0.264)$ & $-0.546^{*}$ & $(0.312)$ \\
\hline Never married & $-0.826^{* * *}$ & $(0.286)$ & -0.375 & $(0.310)$ \\
\hline Moved within 5 years from rural area & -0.387 & $(0.343)$ & -0.520 & $(0.387)$ \\
\hline House is $6+$ years old & $0.383^{\star *}$ & $(0.152)$ & $0.328^{*}$ & $(0.170)$ \\
\hline Electricity available & $-0.490^{* *}$ & $(0.202)$ & $-0.472^{* *}$ & $(0.227)$ \\
\hline Water from rain & $0.499^{*}$ & $(0.273)$ & $1.078^{\star \star \star}$ & $(0.307)$ \\
\hline House is $3-9$ years old & $0.774^{* \star *}$ & $(0.225)$ & $1.014^{\star * \star}$ & $(0.257)$ \\
\hline $\mathrm{HH}$ has radio & $0.384^{* \star *}$ & $(0.138)$ & $0.333^{\star *}$ & $(0.157)$ \\
\hline Head has at least some education & $0.656^{\star \star}$ & $(0.333)$ & $0.671^{*}$ & $(0.372)$ \\
\hline Head has at least college education & 0.915 & $(0.798)$ & $3.090^{\star \star *}$ & $(0.927)$ \\
\hline Spouse has at least 10 years of education & 0.774 & $(0.544)$ & $1.028^{\star}$ & $(0.575)$ \\
\hline Spouse has at least secondary completed & -0.868 & $(0.616)$ & -0.657 & $(0.651)$ \\
\hline Spouse has at least college education & 0.701 & $(0.827)$ & $2.115^{\star \star}$ & $(0.961)$ \\
\hline Max. educ., at least college education & -0.857 & $(0.558)$ & $-1.828^{* *}$ & $(0.732)$ \\
\hline Hai Phong province & -0.646 & $(0.478)$ & -0.893 & $(0.563)$ \\
\hline Thai Binh province & -0.415 & $(0.376)$ & $-0.982^{* *}$ & $(0.466)$ \\
\hline Ninh Binh province & -0.780 & $(0.731)$ & -1.275 & $(0.872)$ \\
\hline Thai Nguyen province & -0.703 & $(0.533)$ & $-2.488^{* *}$ & $(1.041)$ \\
\hline Thua Thien-Hue province & $-3.096^{* \star}$ & $(1.543)$ & $-3.368^{* *}$ & $(1.608)$ \\
\hline Da Nang province & $-4.240^{*}$ & $(2.189)$ & $-3.749^{*}$ & $(2.256)$ \\
\hline Quang Nam province & $-3.056^{*}$ & $(1.607)$ & $-4.252^{* *}$ & (1.699) \\
\hline Quang Ngai province & $-2.761^{* *}$ & (1.356) & -2.034 & $(1.400)$ \\
\hline Binh Dinh province & -1.406 & $(0.869)$ & -1.125 & $(0.917)$ \\
\hline Ho Chi Minh City & $-1.363^{\star \star \star}$ & $(0.518)$ & $-1.019^{*}$ & $(0.548)$ \\
\hline Tay Ninh province & $-1.083^{* *}$ & $(0.530)$ & $-1.209^{* *}$ & $(0.578)$ \\
\hline Binh Duong province & $-1.525^{\star \star}$ & $(0.597)$ & $-2.539^{* * *}$ & $(0.791)$ \\
\hline Dong Nai province & -0.698 & $(0.496)$ & -0.576 & $(0.530)$ \\
\hline Ban Ria-Vung Tau province & $-1.488^{* \star}$ & $(0.575)$ & $-2.916^{\star * *}$ & $(0.822)$ \\
\hline Dong Thap province & -0.683 & $(0.429)$ & $-1.441^{* * *}$ & $(0.521)$ \\
\hline Tra Vinh province & $-1.166^{* \star}$ & $(0.483)$ & $-1.360^{\star *}$ & (0.569) \\
\hline Soc Trang province & $-1.580^{* *}$ & $(0.657)$ & $-1.434^{*}$ & $(0.775)$ \\
\hline Age & $0.074^{\star}$ & $(0.040)$ & $0.225^{\star \star *}$ & $(0.047)$ \\
\hline Age of spouse & $-0.033^{* *}$ & $(0.015)$ & $-0.048^{\star * *}$ & $(0.017)$ \\
\hline Ratio of females in $\mathrm{HH}$ & $1.310^{* * *}$ & $(0.433)$ & $1.305^{\star * *}$ & $(0.487)$ \\
\hline Ratio of students in $\mathrm{HH}$ & $1.193^{* \star *}$ & $(0.395)$ & $1.252^{\star \star \star}$ & $(0.446)$ \\
\hline Age squared/1000 & $-1.444^{\star \star *}$ & $(0.473)$ & $-3.729^{\star \star \star}$ & $(0.583)$ \\
\hline Percentage of bare rock surface in district & 0.020 & $(0.015)$ & 0.023 & $(0.017)$ \\
\hline Distance from district town to a city + & $-0.027^{* *}$ & $(0.011)$ & $-0.034^{\star \star \star}$ & $(0.012)$ \\
\hline Distance from district town to a city ++ & $0.021^{*}$ & $(0.011)$ & $0.035^{\star * \star}$ & $(0.012)$ \\
\hline Total length of road in district $(\mathrm{km})$ & $-0.676^{* *}$ & $(0.338)$ & $-1.850^{\star * *}$ & $(0.396)$ \\
\hline Average annual sunshine duration & $0.480^{*}$ & $(0.274)$ & $1.428^{\star \star \star}$ & $(0.302)$ \\
\hline SDBR from district town to a city+ & $0.015^{\star \star}$ & $(0.008)$ & $0.019^{\star \star}$ & $(0.008)$ \\
\hline SDBR from district town to a city++ & -0.011 & $(0.008)$ & $-0.020^{* *}$ & $(0.009)$ \\
\hline Constant & -0.204 & $(1.099)$ & $-5.401^{* * *}$ & $(1.251)$ \\
\hline
\end{tabular}


Obs 3764

$\chi_{88}^{2}$

$\Delta a_{U L}$

$\triangle a_{F L}$

$\triangle a_{D S D T}$

Note: *significant at a $10 \%$ level.

**significant at a $5 \%$ level.

***significant at a $1 \%$ level.

+ city with population greater than 250,000

++ city with population greater than $1,000,000$.
483.70

0.012

1.777

$-0.108$

0.038

1.766

$-0.109$ 
TABLE 17 EMPLOYMENT STATUS EQUATIONS FOR RURAL/FEMALE/UNSKILLED

\begin{tabular}{|c|c|c|c|c|}
\hline \multirow[t]{2}{*}{ Description } & \multicolumn{2}{|c|}{ Wage-earner } & \multicolumn{2}{|c|}{ Self-employed } \\
\hline & Est. & SE & Est. & SE \\
\hline Age of spouse squared/1000 & $1.483^{* * *}$ & $(0.237)$ & $1.594^{\star \star \star}$ & $(0.370)$ \\
\hline Head's child & $-1.306^{\star \star \star}$ & $(0.385)$ & $-1.076^{*}$ & $(0.553)$ \\
\hline Not immediately related to head & $-1.572^{* * *}$ & $(0.288)$ & $-1.645^{\star * *}$ & $(0.492)$ \\
\hline Never married & $0.941^{* * *}$ & $(0.306)$ & $1.381^{* * *}$ & $(0.432)$ \\
\hline Literate & $0.404^{* * *}$ & $(0.149)$ & 0.212 & $(0.248)$ \\
\hline Head's religion is Catholic & 0.598 ** & $(0.278)$ & 0.645 & $(0.469)$ \\
\hline Head has no religion & $0.470^{* * *}$ & $(0.144)$ & $0.375^{*}$ & $(0.227)$ \\
\hline House is $3-9$ years old & -0.272 * & $(0.139)$ & $0.433^{*}$ & $(0.258)$ \\
\hline Water from rain & 0.379 & $(0.252)$ & 0.447 & $(0.431)$ \\
\hline Flushing toilet & $0.967^{* *}$ & $(0.382)$ & $1.926^{* *}$ & $(0.810)$ \\
\hline Non-flushing toilet & $0.922^{* *}$ & $(0.364)$ & 0.883 & $(0.800)$ \\
\hline Head has at least some education & $0.354^{*}$ & $(0.182)$ & -0.215 & $(0.282)$ \\
\hline Head has at least 8 years of education & $0.613^{* *}$ & $(0.236)$ & $0.830^{*}$ & $(0.457)$ \\
\hline Max. educ., at least 5 years & 0.159 & $(0.168)$ & $-0.455^{\star}$ & $(0.260)$ \\
\hline Max. educ., at least 8 years & -0.282 & $(0.181)$ & -0.261 & $(0.351)$ \\
\hline Age & $0.184^{* * *}$ & $(0.036)$ & $0.178^{* * *}$ & $(0.057)$ \\
\hline Age of spouse & $-0.082 * * *$ & $(0.014)$ & $-0.092^{* \star *}$ & $(0.022)$ \\
\hline Age squared/1000 & $-2.974 * * *$ & $(0.412)$ & $-3.393^{\star * *}$ & $(0.709)$ \\
\hline Distance from district town to city+ & 0.012 * & $(0.007)$ & $-0.070^{* * *}$ & $(0.018)$ \\
\hline Distance from district town to a city++ & $-0.003^{* * *}$ & $(0.001)$ & $-0.005^{* * *}$ & $(0.002)$ \\
\hline Elevation of district town & 0.600 * & $(0.357)$ & $-2.718^{\star *}$ & $(1.156)$ \\
\hline Average annual humidity duration & 0.009 ** & $(0.005)$ & $-0.032^{* * *}$ & $(0.010)$ \\
\hline SDBR from district town to a city+++ & $0.001^{* *}$ & $(0.000)$ & $0.002^{* *}$ & $(0.001)$ \\
\hline Total area over $1500 \mathrm{~m}$ in district & 0.066 & $(0.053)$ & -0.195 & $(0.196)$ \\
\hline Constant & -10.581 ** & $(4.782)$ & $28.744^{* * *}$ & $(9.695)$ \\
\hline Obs & 2302 & & & \\
\hline$\chi_{48}^{2}$ & 539.72 & & & \\
\hline$\Delta a_{U L}$ & 0.012 & & 0.034 & \\
\hline$\Delta a_{F L}$ & 0.219 & & 0.226 & \\
\hline$\triangle a_{D S D T}$ & -0.059 & & -0.058 & \\
\hline
\end{tabular}

Note: *significant at a $10 \%$ level.

$* *$ significant at a $5 \%$ level.

****significant at a $1 \%$ level.

+city with population greater than 10,000

++ city with population greater than 250,000

+++ city with population greater than $1,000,000$. 
TABLE 18 EMPLOYMENT STATUS EQUATION FOR RURAL/FEMALE/SKILLED

\begin{tabular}{|c|c|c|c|c|}
\hline \multirow[t]{2}{*}{ Description } & \multicolumn{2}{|c|}{ Wage-earner } & \multicolumn{2}{|c|}{ Self-employed } \\
\hline & Est. & SE & Est. & $\mathrm{SE}$ \\
\hline Head's child & $-1.552 * * *$ & $(0.413)$ & $-1.087^{* *}$ & $(0.542)$ \\
\hline Not immediately related to head & $-1.053 * * *$ & $(0.386)$ & -0.556 & $(0.483)$ \\
\hline Never married & $0.943^{* \star *}$ & $(0.306)$ & $1.882^{\star \star \star}$ & $(0.399)$ \\
\hline Moved within 5 years from rural area & $-0.885^{* * *}$ & $(0.334)$ & -0.373 & $(0.465)$ \\
\hline Head's religion is Catholic & $-0.447^{*}$ & $(0.252)$ & $-1.599^{* \star *}$ & $(0.376)$ \\
\hline Head's religion is other than none/Buddhism/Catholic & 0.433 & $(0.410)$ & $1.015^{\star *}$ & $(0.473)$ \\
\hline Electricity available & 0.301 * & $(0.175)$ & $0.418^{*}$ & $(0.229)$ \\
\hline House is $3-9$ years old & -0.115 & $(0.141)$ & -0.278 & $(0.175)$ \\
\hline At least 10 years of education & -0.289 & $(0.218)$ & $0.964^{* \star *}$ & $(0.241)$ \\
\hline Head is married & $-1.397^{* * *}$ & $(0.532)$ & $-2.117^{\star *}$ & $(0.745)$ \\
\hline Nghe An province & 0.408 & $(0.362)$ & $1.360^{\star \star \star}$ & $(0.440)$ \\
\hline Ha Tinh province & 1.323 & $(1.027)$ & 1.144 & $(1.122)$ \\
\hline Da Nang province & $-1.698^{* *}$ & $(0.730)$ & -1.493 & $(1.055)$ \\
\hline Ho Chi Minh City & $-1.856 * * *$ & $(0.371)$ & -0.346 & $(0.422)$ \\
\hline Dong Nai province & -0.726 * & $(0.395)$ & 0.739 & $(0.491)$ \\
\hline Ban Ria-Vung Tau province & $-1.030 *$ & $(0.562)$ & -0.862 & $(0.870)$ \\
\hline Age & $0.184^{* \star \star}$ & $(0.041)$ & $0.327^{\star \star *}$ & $(0.054)$ \\
\hline $\mathrm{HH}$ size & $0.308^{* *}$ & $(0.156)$ & 0.311 & $(0.210)$ \\
\hline Head's age & 0.014 & $(0.010)$ & 0.011 & $(0.012)$ \\
\hline Ratio of dependents in $\mathrm{HH}$ & $-1.015^{*}$ & $(0.544)$ & $-1.477^{\star \star}$ & $(0.677)$ \\
\hline Ratio of females in $\mathrm{HH}$ & $1.043^{* *}$ & $(0.432)$ & 0.700 & $(0.535)$ \\
\hline Ratio of children in $\mathrm{HH}$ & -1.382 ** & $(0.614)$ & $-1.921^{* *}$ & $(0.747)$ \\
\hline Ratio of students in $\mathrm{HH}$ & $2.710^{* * *}$ & $(0.504)$ & $2.711^{* \star *}$ & $(0.637)$ \\
\hline Age squared/1000 & $-2.794 * * *$ & $(0.501)$ & $-4.604^{\star \star *}$ & $(0.698)$ \\
\hline $\mathrm{HH}$ size squared/1000 & -0.026 ** & $(0.012)$ & -0.027 & $(0.016)$ \\
\hline Distance from district town to a city+ & $-0.110^{* * *}$ & $(0.029)$ & $-0.103^{* * *}$ & $(0.034)$ \\
\hline Elevation of district town & $1.987^{* * *}$ & $(0.782)$ & 1.089 & $(0.921)$ \\
\hline Proportion of somewhat steep slope (8-15\%) & $0.025^{* * *}$ & $(0.010)$ & 0.013 & $(0.012)$ \\
\hline SDBR from district town to a city + & $0.079^{* * *}$ & $(0.020)$ & $0.053^{* *}$ & $(0.024)$ \\
\hline Mean distance to main road in district & $-0.200^{* * *}$ & $(0.038)$ & $-0.081^{*}$ & $(0.048)$ \\
\hline Length of navigable river in district $(\mathrm{km})$ & -0.004 & $(0.004)$ & $-0.011^{* *}$ & $(0.005)$ \\
\hline Constant & -1.563 * & $(0.909)$ & $-6.095^{\star * *}$ & $(1.187)$ \\
\hline Obs & 3476 & & & \\
\hline$\chi_{62}^{2}$ & 538.73 & & & \\
\hline$\Delta a_{U L}$ & 0.015 & & 0.029 & \\
\hline$\triangle a_{F L}$ & 1.976 & & 1.969 & \\
\hline$\triangle a_{D S D T}$ & -0.084 & & -0.075 & \\
\hline
\end{tabular}

Note: *significant at a $10 \%$ level.

**significant at a $5 \%$ level.

$* * *$ significant at a $1 \%$ level.

+city with population greater than 10,000 . 
TABLE 19 EMPLOYMENT STATUS EQUATION FOR URBAN/MALE/UNSKILLED

\begin{tabular}{|c|c|c|c|c|}
\hline \multirow[t]{2}{*}{ Description } & \multicolumn{2}{|c|}{ Wage-earner } & \multicolumn{2}{|c|}{ Self-employed } \\
\hline & Est. & SE & Est. & SE \\
\hline Literacy & $2.573 * * *$ & $(0.821)$ & $2.552^{* \star \star}$ & $(0.790)$ \\
\hline Head's ethnicity is Kinh & $-2.395^{* * *}$ & $(0.901)$ & $-2.271^{* * *}$ & $(0.849)$ \\
\hline Semi-permanent house & 1.773 *** & $(0.621)$ & $1.889^{* * *}$ & $(0.663)$ \\
\hline Water from rain & 2.529 & $(1.649)$ & 2.349 & $(1.834)$ \\
\hline Water from well & 1.124 & $(0.886)$ & 1.318 & $(0.895)$ \\
\hline Non-flushing toilet & $3.397^{\star \star \star}$ & $(1.008)$ & $3.130^{* \star *}$ & $(1.021)$ \\
\hline Head has at least some education & -1.791 ** & $(0.848)$ & $-2.230^{* * *}$ & $(0.842)$ \\
\hline House is 3-9 years old & 1.102 & $(0.703)$ & $1.394^{\star}$ & $(0.743)$ \\
\hline Spouse has at least 5 years of education & -1.486 * & $(0.793)$ & -1.143 & $(0.815)$ \\
\hline Max. educ. in $\mathrm{HH}$, at least 8 years & -0.979 & $(0.602)$ & -0.696 & $(0.619)$ \\
\hline Age & $0.392 * * *$ & $(0.119)$ & $0.469^{\star \star \star}$ & $(0.131)$ \\
\hline HH owns house & -2.960 ** & $(1.454)$ & $-4.033^{* * *}$ & $(1.316)$ \\
\hline Age squared/1000 & $-5.153 * * *$ & $(1.540)$ & $-7.475^{\star * *}$ & $(1.828)$ \\
\hline Area $\left(\mathrm{km}^{2}\right)$ & $0.098^{* * *}$ & $(0.026)$ & $0.090^{\star * *}$ & $(0.027)$ \\
\hline Percentage of natural forest & $0.187^{* * *}$ & $(0.071)$ & $0.221^{* * *}$ & $(0.070)$ \\
\hline Distance from district town to a city+ & $-2.494^{* * *}$ & $(0.665)$ & $-2.479^{* * *}$ & $(0.666)$ \\
\hline Distance from district town to a city++ & $0.525^{\star \star \star}$ & $(0.190)$ & $0.562^{\star \star \star}$ & $(0.191)$ \\
\hline Distance from district town to a city+++ & -0.403 ** & $(0.160)$ & $-0.434^{* * *}$ & $(0.159)$ \\
\hline Total length of roads in district & $-0.060 * * *$ & $(0.017)$ & $-0.061^{\star * *}$ & $(0.017)$ \\
\hline Average elevation of district & $-0.101 * * *$ & $(0.029)$ & $-0.071^{* *}$ & $(0.030)$ \\
\hline Elevation of district town & $0.193^{* \star *}$ & $(0.053)$ & $0.165^{\star \star \star}$ & $(0.054)$ \\
\hline Percentage of moderate slope in district (4-8\%) & $-2.367^{* \star *}$ & $(0.734)$ & $-2.205^{\star \star \star}$ & $(0.755)$ \\
\hline Average annual precipitation & 6.330 & (5.433) & $9.233^{*}$ & $(5.451)$ \\
\hline Average annual temperature & $-0.391 * *$ & $(0.168)$ & -0.242 & $(0.180)$ \\
\hline Average annual humidity duration & $-0.555^{* *}$ & $(0.225)$ & -0.353 & $(0.243)$ \\
\hline SDBR from district town to a city\# & -0.888 *** & $(0.244)$ & $-0.786^{* * *}$ & $(0.253)$ \\
\hline SDBR from district town to a city+ & $2.003^{\star * *}$ & $(0.538)$ & $1.949^{* * *}$ & $(0.538)$ \\
\hline SDBR from district town to a city++ & $-0.340^{* * *}$ & $(0.126)$ & $-0.368^{\star * *}$ & $(0.126)$ \\
\hline SDBR from district town to a city+++ & $0.314^{\star *}$ & $(0.122)$ & $0.329^{\star \star \star}$ & $(0.122)$ \\
\hline Constant & $650.9 * \star *$ & $(267.3)$ & 403.0 & $(288.7)$ \\
\hline Obs & 225 & & & \\
\hline$\chi_{58}^{2}$ & 213.54 & & & \\
\hline$\Delta a_{U L}$ & 0.085 & & 0.112 & \\
\hline$\Delta a_{F L}$ & 0.644 & & 0.638 & \\
\hline$\triangle a_{D S D T}$ & -0.023 & & -0.029 & \\
\hline
\end{tabular}

Note: *significant at a $10 \%$ level.

**significant at a $5 \%$ level.

***significant at a $1 \%$ level.

\#city with population greater than 50,000

+city with population greater than 100,000

++ city with population greater than 250,000 
+++city with population greater than $1,000,000$.

TABLE 20 EMPLOYMENT STATUS EQUATION FOR URBAN/MALE/SKILLED

\begin{tabular}{|c|c|c|c|c|}
\hline \multirow[t]{2}{*}{ Description } & \multicolumn{2}{|c|}{ Wage-earner } & \multicolumn{2}{|c|}{ Self-employed } \\
\hline & Est. & SE & Est. & SE \\
\hline Never married & $-1.206^{\star \star \star}$ & $(0.274)$ & $-0.530^{* *}$ & $(0.267)$ \\
\hline Divorced/separated/widowed & $-1.597^{\star \star *}$ & $(0.398)$ & $-1.469^{\star \star \star}$ & $(0.435)$ \\
\hline Moved within 5 years from urban area & $-0.769^{* *}$ & $(0.318)$ & $-0.661^{* *}$ & $(0.299)$ \\
\hline Moved within 5 years from rural area & $-0.655^{\star}$ & $(0.392)$ & $-0.879^{\star \star}$ & $(0.397)$ \\
\hline Head's ethnicity is Kinh & -0.354 & $(0.319)$ & -0.403 & $(0.318)$ \\
\hline Electricity available & 0.606 & $(0.580)$ & 1.091 & $(0.670)$ \\
\hline $\mathrm{HH}$ has TV & $0.616^{\star \star *}$ & $(0.213)$ & $0.570^{\star \star *}$ & $(0.213)$ \\
\hline House is $3-9$ years old & $-0.556^{* *}$ & $(0.241)$ & $-0.400^{*}$ & $(0.242)$ \\
\hline At least college education & 0.498 & $(0.344)$ & $1.649^{\star \star \star}$ & $(0.329)$ \\
\hline Head at least 10 years of education & $-0.427^{* *}$ & $(0.203)$ & -0.237 & $(0.204)$ \\
\hline Spouse at least 10 years of education & 0.551 & $(0.413)$ & 0.486 & $(0.417)$ \\
\hline Spouse at least secondary completed & $-0.837^{*}$ & $(0.456)$ & $-0.801^{*}$ & $(0.459)$ \\
\hline Max. educ., at least secondary & $0.430^{*}$ & $(0.223)$ & $0.445^{*}$ & $(0.230)$ \\
\hline Thai Nguyen province & $-1.089^{* *}$ & $(0.480)$ & -0.497 & $(0.447)$ \\
\hline Thanh Hoa province & $1.778^{* *}$ & $(0.842)$ & $2.062^{* *}$ & $(0.851)$ \\
\hline Age & $0.124^{\star \star \star}$ & $(0.042)$ & $0.255^{\star \star \star}$ & $(0.043)$ \\
\hline HH owns house & $0.688^{\star \star \star}$ & $(0.235)$ & 0.192 & $(0.225)$ \\
\hline Ratio of students in $\mathrm{HH}$ & $1.382^{* \star *}$ & $(0.426)$ & $1.129^{\star \star \star}$ & $(0.432)$ \\
\hline Age squared/1000 & $-2.036^{\star \star \star}$ & $(0.490)$ & $-3.920^{* * *}$ & $(0.511)$ \\
\hline Constant & -1.330 & $(1.106)$ & $-3.663^{* * *}$ & (1.158) \\
\hline Obs & 1830 & & & \\
\hline$\chi_{38}^{2}$ & 338.24 & & & \\
\hline$\Delta a_{U L}$ & 0.059 & & 0.071 & \\
\hline$\Delta a_{F L}$ & 0.264 & & 0.261 & \\
\hline$\triangle a_{D S D T}$ & -0.050 & & -0.050 & \\
\hline
\end{tabular}

Note: *significant at a $10 \%$ level.

**significant at a $5 \%$ level.

$* * *$ significant at a $1 \%$ level. 
TABLE 21 EMPLOYMENT STATUS REGRESSION FOR URBAN/FEMALE/UNSKILLED

\begin{tabular}{|c|c|c|c|c|}
\hline \multirow[t]{2}{*}{ Description } & \multicolumn{2}{|c|}{ Wage-earner } & \multicolumn{2}{|c|}{ Self-employed } \\
\hline & Est. & SE & Est. & SE \\
\hline Never married & 0.404 & $(0.442)$ & $1.153^{* *}$ & $(0.509)$ \\
\hline Divorced/separated/widowed & $-0.516 *$ & $(0.309)$ & 0.397 & $(0.480)$ \\
\hline Literate & 0.415 & $(0.296)$ & 0.874 * & $(0.472)$ \\
\hline Head has no religion & -0.281 & $(0.243)$ & -0.431 & $(0.334)$ \\
\hline Head's ethnicity is Kinh & $1.247^{* \star *}$ & $(0.314)$ & 0.407 & $(0.392)$ \\
\hline House is $6+$ years old & -0.322 & $(0.266)$ & -0.366 & $(0.387)$ \\
\hline Electricity available & 0.655 & $(0.524)$ & 1.637 * & $(0.945)$ \\
\hline House is $3-9$ years old & $1.269^{* \star *}$ & $(0.286)$ & 0.541 & $(0.439)$ \\
\hline Head, at least some education & $0.916 * *$ & $(0.371)$ & $0.910^{*}$ & $(0.517)$ \\
\hline Max educ., at least 10 years & $-0.745^{* * *}$ & $(0.262)$ & $-0.884^{* *}$ & $(0.403)$ \\
\hline Age & $0.199 * * \star$ & $(0.061)$ & $0.293^{* * *}$ & $(0.084)$ \\
\hline Ratio of dependents in $\mathrm{HH}$ & $-1.806 * *$ & $(0.792)$ & -1.633 & $(1.134)$ \\
\hline Ratio of students in $\mathrm{HH}$ & $2.696^{* * *}$ & $(0.923)$ & 1.440 & $(1.230)$ \\
\hline Age squared/1000 & $-2.223 * * *$ & $(0.711)$ & $-4.171^{\star * *}$ & $(1.069)$ \\
\hline Constant & $-5.979 * * *$ & $(1.471)$ & $-8.046^{* * *}$ & (1.983) \\
\hline Obs & 458 & & & \\
\hline$\chi_{28}^{2}$ & 143.46 & & & \\
\hline$\Delta a_{U L}$ & 0.040 & & 0.046 & \\
\hline$\Delta a_{F L}$ & 0.162 & & 0.150 & \\
\hline$\triangle a_{D S D T}$ & -0.071 & & -0.069 & \\
\hline
\end{tabular}

Note: *significant at a $10 \%$ level.

**significant at a $5 \%$ level.

****significant at a $1 \%$ level. 
TABLE 22 EMPLOYMENT STATUS EQUATIONS FOR URBAN/SKILLED/FEMALE

\begin{tabular}{|c|c|c|c|c|}
\hline \multirow[t]{2}{*}{ Description } & \multicolumn{2}{|c|}{ Wage-earner } & \multicolumn{2}{|c|}{ Self-employed } \\
\hline & Est. & SE & Est. & SE \\
\hline Age of spouse squared/1000 & -0.332 & $(0.279)$ & -0.455 & $(0.292)$ \\
\hline Spouse & $-0.598^{* * *}$ & $(0.190)$ & $-0.693^{* * *}$ & $(0.216)$ \\
\hline Not immediately related to head & $-0.542 * *$ & $(0.218)$ & -0.289 & $(0.227)$ \\
\hline Never married & 0.226 & $(0.220)$ & $0.838^{\star \star \star}$ & $(0.231)$ \\
\hline Head's religion is Catholic & 0.222 & $(0.291)$ & 0.406 & $(0.305)$ \\
\hline Head's religion is other than none/Buddhism/Catholic & -0.556 & $(0.457)$ & $-1.076^{*}$ & $(0.583)$ \\
\hline Temporary house & $-1.163^{* *}$ & $(0.576)$ & -0.888 & (0.625) \\
\hline House is $3-9$ yrs old & $-0.299 * *$ & $(0.140)$ & $-0.327^{\star *}$ & $(0.154)$ \\
\hline At least 8 years of education & 0.217 & $(0.147)$ & $0.465^{\star \star \star}$ & $(0.171)$ \\
\hline Head has at least college education & -0.524 & $(0.385)$ & $1.254^{\star \star \star}$ & $(0.348)$ \\
\hline Spouse has at least some education & -0.524 & $(0.456)$ & $-0.843^{*}$ & $(0.466)$ \\
\hline Max. educ., at least college education & -0.225 & $(0.215)$ & $0.429^{\star}$ & $(0.233)$ \\
\hline Age & $0.234^{* * *}$ & $(0.038)$ & $0.312^{* \star *}$ & $(0.044)$ \\
\hline $\mathrm{HH}$ size & -0.050 & $(0.034)$ & -0.047 & $(0.037)$ \\
\hline Log of the living area & -0.151 & $(0.138)$ & $-0.281^{*}$ & $(0.151)$ \\
\hline Age of spouse & 0.035 & $(0.022)$ & $0.042^{*}$ & $(0.023)$ \\
\hline Ratio of children in $\mathrm{HH}$ & -0.449 & $(0.484)$ & $-1.324^{* *}$ & (0.539) \\
\hline Ratio of students in $\mathrm{HH}$ & $1.187^{* \star *}$ & $(0.429)$ & $1.319^{\star * \star}$ & $(0.472)$ \\
\hline Age squared/1000 & $-0.003 * * *$ & $(0.000)$ & $-0.005^{\star \star *}$ & $(0.001)$ \\
\hline Arable land in district $\left(\mathrm{km}^{2}\right)$ & -0.002 & $(0.002)$ & $-0.003^{*}$ & $(0.002)$ \\
\hline Logarithmic population of district & $-0.558^{* * *}$ & $(0.086)$ & $-0.294^{\star * *}$ & $(0.096)$ \\
\hline Distance from district town to a city+ & 0.075 & $(0.049)$ & 0.084 & $(0.055)$ \\
\hline Distance from district town to a city+++ & $0.008^{* *}$ & $(0.003)$ & $0.017^{\star \star \star}$ & $(0.004)$ \\
\hline Length of main road $(\mathrm{km})$ & 0.006 & $(0.004)$ & $0.014^{* \star \star}$ & $(0.004)$ \\
\hline SDBR from district town to a city++ & $0.004^{* * *}$ & $(0.001)$ & $0.002^{* * *}$ & $(0.001)$ \\
\hline SDBR from district town to a city+++ & $-0.006^{* \star}$ & $(0.003)$ & $-0.012^{*}$ & $(0.003)$ \\
\hline Mean distance to main road in district & $-0.423^{* *}$ & $(0.189)$ & -0.309 & $(0.209)$ \\
\hline Constant & 3.975 & (1.295) & -0.127 & $(1.450)$ \\
\hline Obs & 1899 & & & \\
\hline$\chi_{54}^{2}$ & 556.96 & & & \\
\hline$\Delta a_{U L}$ & 0.041 & & 0.069 & \\
\hline$\Delta a_{F L}$ & 0.187 & & 0.186 & \\
\hline$\triangle a_{D S D T}$ & -0.029 & & -0.031 & \\
\hline
\end{tabular}

Note: *significant at a $10 \%$ level.

$* *$ significant at a $5 \%$ level.

$* * *$ significant at a $1 \%$ level.

+city with population greater than 10,000

++ city with population greater than 250,000

+++ city with population greater than $1,000,000$. 